\title{
Global distribution and climate forcing of marine organic aerosol: 1. Model improvements and evaluation
}

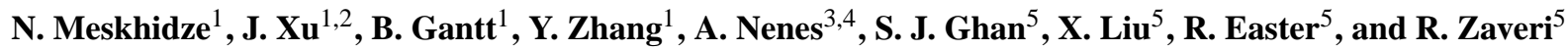 \\ ${ }^{1}$ Department of Marine, Earth, and Atmospheric Sciences, North Carolina State University, Raleigh, NC, USA \\ ${ }^{2}$ Chinese Research Academy of Environment Sciences, No. 8 Dayangfang, Beiyuan, Chaoyang District, \\ Beijing 100012, China \\ ${ }^{3}$ School of Earth and Atmospheric Sciences, Georgia Institute of Technology, Atlanta, GA, USA \\ ${ }^{4}$ School of Chemical and Biomolecular Engineering, Georgia Institute of Technology, Atlanta, GA, USA \\ ${ }^{5}$ Atmospheric Sciences \& Global Change Division, Pacific Northwest National Laboratory, Richland, WA, USA
}

Received: 24 May 2011 - Published in Atmos. Chem. Phys. Discuss.: 1 July 2011

Revised: 19 October 2011 - Accepted: 8 November 2011 - Published: 23 November 2011

\begin{abstract}
Marine organic aerosol emissions have been implemented and evaluated within the National Center of Atmospheric Research (NCAR)'s Community Atmosphere Model (CAM5) with the Pacific Northwest National Laboratory's 7-mode Modal Aerosol Module (MAM-7). Emissions of marine primary organic aerosols (POA), phytoplanktonproduced isoprene- and monoterpenes-derived secondary organic aerosols (SOA) and methane sulfonate $\left(\mathrm{MS}^{-}\right)$are shown to affect surface concentrations of organic aerosols in remote marine regions. Global emissions of submicron marine POA is estimated to be 7.9 and $9.4 \mathrm{Tg} \mathrm{yr}^{-1}$, for the Gantt et al. (2011) and Vignati et al. (2010) emission parameterizations, respectively. Marine sources of SOA and particulate $\mathrm{MS}^{-}$(containing both sulfur and carbon atoms) contribute an additional 0.2 and $5.1 \mathrm{Tg} \mathrm{yr}^{-1}$, respectively. Widespread areas over productive waters of the Northern Atlantic, Northern Pacific, and the Southern Ocean show marine-source submicron organic aerosol surface concentrations of $100 \mathrm{ng} \mathrm{m}^{-3}$, with values up to $400 \mathrm{ng} \mathrm{m}^{-3}$ over biologically productive areas. Comparison of long-term surface observations of water insoluble organic matter (WIOM) with POA concentrations from the two emission parameterizations shows that despite revealed discrepancies (often more than a factor of 2), both Gantt et al. (2011) and Vignati et al. (2010) formulations are able to capture the magnitude of marine organic aerosol concentrations, with the Gantt et al. (2011) parameterization attaining better seasonality. Model simulations show that the mixing state of the marine POA can impact the surface number concentration of cloud condensation nuclei (CCN). The largest increases (up to $20 \%$ ) in CCN (at a supersaturation
\end{abstract}

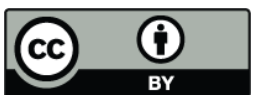

Correspondence to: N. Meskhidze (nmeskhidze@ncsu.edu)
$(S)$ of $0.2 \%$ ) number concentration are obtained over biologically productive ocean waters when marine organic aerosol is assumed to be externally mixed with sea-salt. Assuming marine organics are internally-mixed with sea-salt provides diverse results with increases and decreases in the concentration of $\mathrm{CCN}$ over different parts of the ocean. The sign of the $\mathrm{CCN}$ change due to the addition of marine organics to seasalt aerosol is determined by the relative significance of the increase in mean modal diameter due to addition of mass, and the decrease in particle hygroscopicity due to compositional changes in marine aerosol. Based on emerging evidence for increased $\mathrm{CCN}$ concentration over biologically active surface ocean areas/periods, our study suggests that treatment of sea spray in global climate models (GCMs) as an internal mixture of marine organic aerosols and sea-salt will likely lead to an underestimation in $\mathrm{CCN}$ number concentration.

\section{Introduction}

The indirect effect of anthropogenic aerosols remains as the largest source of uncertainty for climate projections (IPCC, 2007). To characterize the effects of anthropogenic aerosol, the impact of all aerosols (anthropogenic and natural) on the earth system, and the role of "aerosols before pollution" (Andreae, 2007) must be understood. One of the largest uncertainties of the aerosol-cloud system is the emission rate of natural aerosols, especially over marine areas. Marine aerosols are important for the global cloud condensation nuclei $(\mathrm{CCN})$ budget, as they contribute considerably to the overall aerosol load, are emitted from a large surface area, and can strongly affect radiative properties and the lifetime of marine stratiform clouds (Klein and Hartmann, 1993). Marine aerosols could be particularly

Published by Copernicus Publications on behalf of the European Geosciences Union. 
important for understanding the cloud-mediated effects of aerosols on climate, because cloud properties respond nonlinearly to aerosols and are most sensitive to $\mathrm{CCN}$ changes when their background concentration is low (Platnick and Twomey, 1994). This sensitivity is evident in measured cloud droplet number concentration (CDNC) over the remote oceans, which ranges from tens per $\mathrm{cm}^{3}$ in biologically inactive regions to hundreds per $\mathrm{cm}^{3}$ under biologically active conditions (Andreae, 2007). Thus, factors that regulate the concentration of marine aerosols and the resulting reflectivity of low-level marine clouds can critically affect the climate system as a whole (e.g. Randall et al., 1984; Stevens et al., 2005). Despite their importance, the source strength and chemical composition of marine aerosols remain poorly quantified (O'Dowd and de Leeuw, 2007; Andreae and Rosenfeld, 2008). Therefore, most modeling studies that have attempted to simulate the atmosphere before the advent of humans do not represent natural marine aerosols realistically. Instead, to compensate for missing natural marine aerosol sources, global aerosol-climate models impose lower bounds on CDNC or aerosol number concentration over remote marine areas (Lohmann et al., 1999, 2007; Takemura et al., 2005; Wang and Penner, 2009). When these possibly unphysical constraints are removed, the simulated aerosol indirect effect can change by up to $80 \%$ (Kirkevåg et al., 2008; Hoose et al., 2009). Changes of this magnitude can have profound effects on the model-predicted extent of human-induced climate change and highlight the need for improved modeling of marine aerosol number size distribution and chemical composition over pristine marine regions.

Natural aerosols over remote oceanic regions consist mainly of a mixture of sea-salt particles, organics, and sulfates from the oxidation of biogenic dimethyl sulfide (DMS) with contributions from mineral dust and smoke from wildfires in some regions (Andreae, 2007). Sea-salt has been proposed to be a major component of marine aerosol over the regions where wind speeds are high and/or other aerosol sources are weak (O’Dowd et al., 1997; Murphy et al., 1998; Quinn et al., 1998). At typical wind speeds encountered during the cruises, sea-salt have been shown to be present in aerosol from $10 \mathrm{~nm}$ to several micrometers in diameter with a total number concentration above $100 \mathrm{~cm}^{-3}$ (Geever et al., 2005; Clarke et al., 2006; Smith, 2007). Using a coupled global aerosol-climate model with a size-resolved seasalt aerosol parameterization, Ma et al. (2008) estimated that global direct and first indirect radiative forcings associated with sea-salt aerosol were $-0.60 \mathrm{~W} \mathrm{~m}^{-2}$ and $-1.34 \mathrm{~W} \mathrm{~m}^{-2}$, respectively.

In addition to sea-salt and DMS products, significant concentrations of submicron organic aerosols have been identified in marine environments (Novakov et al., 1997; Ellison et al., 1999; Putaud et al., 2000; O'Dowd et al., 2004; Cavalli et al., 2004; Yoon et al., 2007; Pio et al., 2007; Sciare et al., 2009; Russell et al., 2010; Hultin et al., 2010). Marinesource organic aerosols are particularly abundant over re- gions of enhanced oceanic biological activity, where they make up to $63 \%$ of the accumulation mode mass (O'Dowd et al., 2004) with concentrations up to $3.8 \mu \mathrm{g} \mathrm{m}^{-3}$ (Ovadnevaite et al., 2011). These organic aerosols have been broadly classified as primary or secondary based on chemical composition (Ceburnis et al., 2008), although this classification has recently been subjected to criticism (Rinaldi et al., 2010). Bubble bursting processes that emit sea-salt aerosols into the marine boundary layer also lead to the emission of marine primary organic aerosols (POA) composed of biogenic secretions and bacterial/viral debris (Blanchard and Woodcock, 1957; Middlebrook et al., 1998; O'Dowd et al., 2004; Leck and Bigg, 2005). Owing to their enhanced fine-mode concentration and surface active nature, these small insoluble organic particles have been proposed to influence both concentration and $\mathrm{CCN}$ activity of remote marine aerosols (O'Dowd et al., 2004; Leck and Bigg, 2007; Moore et al., 2008). However, to date laboratory and modeling studies have reported widely inconsistent results, suggesting increase, decrease or no effect of marine POA on CCN number concentration (Blanchard, 1963; Sellegri et al., 2006; Tyree et al., 2007; Fuentes et al., 2010; Westervelt et al., 2011).

Phytoplankton can also emit several types of biogenic volatile organic compounds (BVOCs), such as isoprene, monoterpenes, and amines that have the potential to form secondary organic aerosols (SOA) (Bonsang et al., 1992; Shaw et al., 2003, 2010; Yassaa et al., 2008; Facchini et al., 2008a; Sabolis, 2010). Marine isoprene emissions and their impact on SOA formation have been the subject of several recent studies (Arnold et al., 2009; Gantt et al., 2009; Luo and Yu, 2010; Myriokefalitakis et al., 2010). While the magnitude of SOA-forming potential from marine isoprene has been estimated to be small on the global scale (Arnold et al., 2009), size-resolved local/regional contributions are still not well understood (Gantt et al., 2009). It has been proposed that SOA produced from plankton-emitted isoprene can act synergistically with the established mechanisms of DMSderived sulfate and sea-salt aerosols to change the chemical composition and number concentration of marine $\mathrm{CCN}$ (Meskhidze and Nenes, 2006).

In this work, we use the National Center of Atmospheric Research (NCAR)'s Community Atmosphere Model (CAM5), which includes the Pacific Northwest National Laboratory's 7-mode Modal Aerosol Model (MAM-7), to examine the potential effects of marine organic aerosols on climate assessments. Our model simulations consider three main effects of marine-induced organic aerosols on marine clouds: (1) CCN number concentration; (2) cloud microphysical and radiative properties; and (3) the range in the assessments of shortwave cloud forcing. Calculations are conducted using different mixing states and emission mechanisms of marine organic aerosols, and different cloud droplet activation parameterizations. This study is the first of a twopart sequence and focuses on the impacts of marine organic emissions on aerosol abundance, chemical composition, and 
CCN activity. The second part (Meskhidze et al., 2011) will focus on the impact of these emissions on cloud microphysical properties and shortwave radiative forcing.

\section{Model and methods}

\subsection{Model description}

CAM5 is a general circulation model (GCM) with a complete representation of the aerosol lifecycle, a physicallybased treatment of aerosol activation, double-moment cloud microphysics, and interactive cloud radiative properties. The model simulations are conducted at $1.9^{\circ} \times 2.5^{\circ}$ horizontal grid resolution with a vertical resolution of 30 layers from the surface to $2.19 \mathrm{hPa}$. CAM5/MAM-7 (hereinafter referred to as CAM5) treats aerosols as internal mixtures of all major species within each of seven externally-mixed modes whose properties are given in Table 1. A detailed description of CAM5 can be found at http://www.cesm.ucar.edu/models/ cesm1.0/cam and Neale et al. (2010). Of particular importance to this study is the treatment of aerosol water uptake and activation. Water uptake is determined using Köhler theory (Ghan and Zaveri, 2007) with a parameterized treatment of aerosol hygroscopicity values equivalent to the $\kappa$-Köhler theory approach of Petters and Kreidenweis (2007). Aerosol activation to form cloud droplets is calculated by the scheme of Abdul-Razzak and Ghan (2000) (hereinafter referred to as AR-G), which is based on all modes of the aerosol size distribution and the volume-weighted hygroscopicity in each mode. Treating the competition between modes during droplet formation is important when the surface area of the accumulation and coarse modes of the aerosol are comparable (Ghan et al., 1998).

Anthropogenic emissions, including sulfur dioxide $\left(\mathrm{SO}_{2}\right)$, POA, and black carbon (BC) are from the Lamarque et al. (2010) Intergovernmental Panel on Climate Change (IPCC) Fifth Assessment Report (AR5) emission data set, updated by Bond et al. (2007) and Junker and Liousse (2008). Injection heights and size distributions of primary emitted particles and precursor gases follow the Aerosol Comparisons between Observations and Models (AEROCOM) protocols (Dentener et al., 2006). SOA production from five (lumped) biogenic and anthropogenic hydrocarbon emissions is prescribed using monthly-averaged VOC emissions from the MOZART-2 dataset (Horowitz et al., 2003) for the year 1997 and assumed SOA yields for each different VOC species to form a single lumped semi-volatile gas that then condenses onto each aerosol mode using gas-to-particle mass transfer expressions (Seinfeld and Pandis, 2006) that are integrated over the size distribution of each mode (Binkowski and Shankar, 1995). Sea-salt emissions are calculated online using Mårtensson et al. (2003) for particles $<2.8 \mu \mathrm{m}$ in dry diameter and Monahan et al. (1986) for particles $>2.8 \mu \mathrm{m}$ in dry diameter, and assumed upper cut off diameters of 0.08 ,
Table 1. Size range and chemical components of the seven aerosol modes in CAM5.

\begin{tabular}{|c|c|c|}
\hline Mode & $\begin{array}{l}\text { Diameter } \\
\text { Sizes }(\mu \mathrm{m})^{\mathrm{a}}\end{array}$ & Chemical Constituents Included \\
\hline Atiken & $0.01-0.08$ & $\begin{array}{l}\mathrm{SO}_{4}^{2-}, \mathrm{NH}_{4}^{+}, \mathrm{SOA}, \text { sea-salt, } \\
\text { marine } \mathrm{POA}^{\mathrm{b}}\end{array}$ \\
\hline Accumulation & $0.08-0.3$ & $\begin{array}{l}\mathrm{SO}_{4}^{2-}, \mathrm{NH}_{4}^{+}, \mathrm{BC}, \mathrm{SOA}, \mathrm{POA}, \\
\text { sea-salt, marine } \mathrm{POA}^{\mathrm{b}}\end{array}$ \\
\hline Fine soil dust & $0.1-2.0$ & $\mathrm{SO}_{4}^{2-}, \mathrm{NH}_{4}^{+}$, dust \\
\hline Fine sea-salt & $0.3-1.0$ & $\begin{array}{l}\mathrm{SO}_{4}^{2-}, \mathrm{NH}_{4}^{+}, \text {sea-salt, } \\
\text { marine } \mathrm{POA}^{\mathrm{b}}\end{array}$ \\
\hline Primary carbon & $0.05-0.3$ & $\mathrm{BC}, \mathrm{POA}$ \\
\hline Coarse soil dust & $2.0-10.0$ & $\mathrm{SO}_{4}^{2-}, \mathrm{NH}_{4}^{+}$, dust \\
\hline Coarse sea-salt & $1.0-10.0$ & $\begin{array}{l}\mathrm{SO}_{4}^{2-}, \mathrm{NH}_{4}^{+}, \text {sea-salt, } \\
\text { marine } \mathrm{POA}^{\mathrm{b}}\end{array}$ \\
\hline
\end{tabular}

a These size ranges are only approximate, as each mode has a log-normal size distribution with median diameters that vary spatially and temporally.

${ }^{\mathrm{b}}$ Constituents only included in model simulations with marine organic emissions.

$0.3,1.0$ and $10 \mu \mathrm{m}$ to determine the sea-salt number and mass emissions into the Aitken, accumulation, and fine/coarse seasalt modes. Dust emissions are also calculated online using the Dust Entrainment and Deposition (DEAD) scheme of Zender et al. (2003). Primary aerosol emissions specify both mass and number emissions. With the exception of sea-salt (which is emitted as a number and then converted to mass), the aerosol number emission is calculated based on the size distribution of each aerosol type. Aerosol wet removal is calculated using the wet removal routine of Rasch et al. (2000) and Barth et al. (2000) with modifications for the consistency with cloud macro- and microphysics. The routine treats incloud scavenging (the removal of cloud-borne aerosol particles) and below cloud scavenging (the removal of interstitial aerosol particles by precipitation particles through impaction and Brownian diffusion). Aerosol dry deposition velocities are calculated using the (Zhang et al., 2001) parameterization with the CAM5 land-use and surface layer information, while particle gravitational settling velocities are calculated at layers above the surface (Seinfeld and Pandis, 2006). Both velocities depend on particle wet size (Neale et al., 2010).

\subsection{Model improvement}

In this work, several updates have been developed and implemented into the CAM5 model to allow for improved quantification of marine organics and aerosol radiative effects. These model updates, which are described in the following sections, include parameterizations for marine primary organics and BVOC emissions, modifications to marine SOA production pathways, extension of the AR-G aerosol activation 
parameterization to allow treatment of the influence of organic surfactants on the activation process, and implementation of an alternate aerosol activation parameterization.

\subsubsection{Marine primary organic aerosol}

The two distinct online emission mechanisms for marine POA that have been implemented in CAM5 in this work are described in detail by Vignati et al. (2010) and Gantt et al. (2011). Both parameterizations compute organic mass fraction of sea spray $\left(\mathrm{OM}_{\mathrm{SSA}}\right)$, and use it to estimate the emissions of marine POA based on the default sea spray emission rates. The major difference between the two $\mathrm{OM}_{\mathrm{SSA}}$ emissions schemes is the mechanism that determines the organic enrichment of sea spray. In the Vignati et al. (2010) scheme which updates O'Dowd et al. (2008), the organic fraction of sea spray is determined using a positive linear relationship with ocean surface chlorophyll- $a$ concentration ([chl- $a]$ ) obtained from the Sea Wide Field-of-view Sensor (SeaWiFS) using the OC4v4 algorithm (O'Reilly et al., 1998) for the years 2000-2007. In addition to [chl-a], the Gantt et al. (2011) scheme considers wind speed and aerosol diameter $\left(D_{\mathrm{p}}\right)$ in determining the $\mathrm{OM}_{\mathrm{SSA}}$. The wind speed dependence of the Gantt et al. (2011) parameterization is based on a conceptual relationship between the organic enrichment at the air-sea interface and surface wind speed, while the aerosol size dependence is based on measurements of Facchini et al. (2008b). The multi-variable logistic regression between $\mathrm{OM}_{\mathrm{SSA}}$ and [chl- $a$ ], $10-\mathrm{m}$ wind speed $\left(U_{10}\right)$, and aerosol diameter in Gantt et al. (2011) is given as:

$$
\begin{array}{r}
\mathrm{OM}_{\mathrm{SSA}}\left(\operatorname{chl}-a, U_{10}, D_{\mathrm{p}}\right)=\frac{\frac{1}{1+\exp \left(-2.63[\mathrm{chl}-a]+0.18 U_{10}\right)}}{1+0.03 \exp \left(6.81 D_{\mathrm{p}}\right)} \\
+\frac{0.03}{1+\exp \left(-2.63[\mathrm{chl}-a]+0.18 U_{10}\right)}
\end{array}
$$

The resulting $\mathrm{OM}_{\mathrm{SSA}}$ parameterization is applicable to areas with vastly different winds and [chl- $a$ ] and can give the size-resolved organic carbon fraction of sea spray aerosols globally, using model-predicted $U_{10}$ and remotely-sensed [chl- $a$ ] data.

The Vignati et al. (2010) parameterization is derived for the bulk of submicron aerosols and does not include information on size distribution. To make it consistent with the Gantt et al. (2011) parameterization, the same Facchini et al. (2008b) size distribution is applied to the Vignati et al. (2010) parameterization as follows:

$$
\begin{aligned}
\mathrm{OM}_{\mathrm{SSA}}\left(\operatorname{chl}-a, D_{\mathrm{p}}\right) & =\frac{0.435[\operatorname{chl}-a]+0.138}{1+0.03 \exp \left(6.81 D_{\mathrm{p}}\right)} \\
+ & 0.03 \times(0.435[\operatorname{chl}-a]+0.138)
\end{aligned}
$$

The marine primary organic emission parameterizations implemented in CAM5 also incorporate the change in density when transitioning between sea-salt and organics as described in Gantt et al. (2009). The magnitude of $\mathrm{OM}_{\mathrm{SSA}}$ can influence the hygroscopicity and thus the growth factor of the aerosol as described in Gantt et al. (2011). For marine POA emissions described by Eq. (2) to be consistent with the rates from Vignati et al. (2010), no growth factor effects were considered (GF $=1)$ and the $D_{\mathrm{p}}$ in Eqs. (1) and (2) is assumed to represent a dry diameter. Since marine POA and sea-salt are thought to have similar emission mechanisms (i.e. bubble bursting), the modeled marine primary organics are emitted into the same aerosol modes that contain seasalt (i.e. Aitken, accumulation, and fine/coarse sea-salt). As the Mårtensson et al. (2003) parameterization was developed for a synthetic sea-water (without organics) and in light of observational and laboratory evidence for the external mixtures of sea-salt and marine POA (Leck and Bigg, 2007; Hawkins and Russell, 2010; Hultin et al., 2010) and changes in number and size distribution of marine aerosol during high biological productivity (Andreae et al., 2007; Yoon et al., 2007; Fuentes et al., 2010), two different approaches are used for modeling marine POA: externally-mixed and internallymixed (with sea-salt) emissions. In both approaches, the organic mass fraction of sea spray in Aitken, accumulation, and fine/coarse sea-salt modes (see Table 1) is calculated using Eqs. (1) and (2). In the externally-mixed emission approach, the added marine POA mass emissions are accompanied by corresponding increases to sea spray number emissions into 4 model modes, based on the assumed size distribution for sea spray emissions (from Mårtensson et al., 2003 and Monahan et al., 1986). The externally-mixed approach increases the aerosol number emission within the aerosol modes and slightly decreases the mean modal diameter of the emissions (by $\sim 4 \%$ when $\mathrm{OM}_{\mathrm{SSA}}=0.5$ ) due to the lower density of marine POA relative to sea-salt. In the internally-mixed approach, only the sea spray aerosol mass is enhanced by addition of organics. Sea-spray number emissions into the 4 model modes are unchanged; the additional marine POA alters the chemical composition and increases the mean modal diameter of the emissions (by $\sim 10 \%$ when $\mathrm{OM}_{\mathrm{SSA}}=0.5$ ). As the number concentration of organic aerosols in marine environments is relatively unconstrained, addition of marine POA emissions as both external and internal mixtures to CAM5 using the OMSSA from Eqs. (1) and (2) is believed to cover the range of possible scenarios by which marine carbonations aerosols can influence the CCN activity of aerosols over the ocean.

For both the internally- and externally-mixed emission approaches, the aerosols in each mode are assumed to be internally-mixed and the hygroscopicity is calculated as mixture of a volume-weighted average of the hygroscopicity values of individual components (Petters and Kreidenweis, 2007). Few observational data are available for the physical and chemical properties of marine POA; so, the chemical properties of sub- and super-micron marine POA are assumed to be that of terrestrial POA, i.e. a hygroscopicity value $(\kappa)$ of $10^{-10}$ and a density of $1000 \mathrm{~kg} \mathrm{~m}^{-3}$ (Neale et al., 2010). However, in light of higher hygroscopicity values 
of marine POA inferred by Cavalli et al. (2004) and Moore et al. (2008) and the sensitivity of aerosol indirect forcing to the hygroscopicity of terrestrial POA (Liu and Wang, 2010), calculations documenting the sensitivity of our results to an increased marine POA hygroscopicity will be presented in the second part of this study.

\subsubsection{Marine SOA}

It has been well established that marine photosynthetic organisms emit a suite of BVOCs. In this study we consider DMS, isoprene, and monoterpenes (e.g. $\alpha$ - and $\beta$-pinene, and d-limonene). DMS fluxes in CAM5 are from Dentener et al. (2006), where the oceanic DMS emissions are from simulations by the Laboratoire de Météorologie DynamiqueZoom (LMDZ) general circulation model (Boucher et al., 2003), using Kettle et al. (1999) seawater DMS concentrations and the Nightingale et al. (2000) air-ocean exchange parameterization. Previous modeling studies (e.g. Chin et al., 2000; Boucher et al., 2003; Easter et al., 2004; Myriokefalitakis et al., 2010) have found that over $90 \%$ of atmospheric DMS is converted to $\mathrm{SO}_{2}$, but $1-2 \mathrm{Tg} \mathrm{S} \mathrm{yr}^{-1}$ are converted to gaseous methanesulfonic acid which condenses to particulate methane sulfonate $\left(\mathrm{MS}^{-}\right)$. To account for the contribution of $\mathrm{MS}^{-}$to both sulfur and SOA budgets (notice that particulate $\mathrm{MS}^{-}$contains both sulfur and carbon atoms) in CAM5, we have implemented a temperature-dependent empirical equation for the $\mathrm{MS}^{-} / \mathrm{nss}-\mathrm{SO}_{4}^{2-}$ molar ratio proposed by Bates et al. (1992). This formulation compares well with both the observational data (Bates et al., 1992) and the results of complex multiphase chemical models of DMS oxidation (Campolongo et al., 1999). In the model, advection as well as dry and wet deposition of is treated in a way similar to $\mathrm{SO}_{4}^{2-}$.

The marine emissions of isoprene and monoterpenes are calculated using the Gantt et al. (2009) scheme. This emission module accounts for phytoplankton abundance in the surface ocean column, their speciation, $U_{10}$, sea surface temperature (SST), and the incoming solar radiation at a specific water depth based on diffuse attenuation of sunlight throughout the ocean column. Isoprene production rates as a function of light intensity for various phytoplankton groups are taken from Gantt et al. (2009). Production rates for marine $\alpha$ - and $\beta$-pinene, and d-limonene are scaled to isoprene emissions based on the measurements of Sabolis (2010). Both isoprene and monoterpene emission rates used in this study are based on laboratory measurements from different phytoplankton functional groups (i.e. diatoms, coccolithophores, dinoflagellates) under variable environmental conditions (i.e. light and temperature). For the irreversible conversion of marine BVOC to SOA, a $28.6 \%$ mass yield is assumed for isoprene (Surratt et al., 2010), $30 \%$ for $\alpha$ - and $\beta$-pinene, and $60 \%$ for d-limonene (Lee et al., 2006). Unlike marine POA emissions that are added to CAM5 as an additional mass and number, the SOA and are condensed to pre-existing particles in different aerosol modes (based on their surface areas) and therefore can only influence total mass and chemical composition of individual aerosol modes. Since the properties of marine SOA are not well characterized, they are set to the same values as that of the terrestrial SOA in CAM5, i.e. a $\kappa=0.14$ and a density of $1000 \mathrm{~kg} \mathrm{~m}^{-3}$ (Neale et al., 2010).

\subsubsection{Surfactant effect}

Models of cloud droplet formation based on laboratory studies with idealized composition of $\mathrm{CCN}$ suggest that organic solutes can lower surface tension $(\sigma)$, one of the factors that control the vapor pressure of small droplets. Chemical effects on cloud droplet number concentration could be particularly pronounced for shallow marine clouds that are characterized by low droplet number concentrations and weak updraft velocities (compared to continental clouds) (Rissman et al., 2004). Here we carry out an extension of AR-G parameterization in CAM5 to include explicit treatment of surface-active species by implementing the modified multimode parameterization of Rissman et al. (2004). Recent surface tension measurements for marine dissolved organic matter have shown that surface tension depression for marine organics can be represented by Szyskowski-Langmuir adsorption isotherm (Langmuir, 1917) as a function of carbon concentration, $\mathrm{C}$ :

$\sigma=\sigma_{\mathrm{w}}-\alpha T \ln (1+\beta C)$

where $\sigma_{\mathrm{w}}$ is surface tension of water (i.e. an "infinitely diluted" sample), $T$ is the absolute temperature, and $\alpha$ and $\beta$ are empirical constants. Surfactant effects of marine organics are explored using two different sets of constants: $\alpha=1.7 \times 10^{-4} \mathrm{~N} \mathrm{~m}^{-1} \mathrm{~K}^{-1}$ and $\beta=11.861 \mathrm{~mol}^{-1}$ from Cavalli et al. (2004) and $\alpha=2.952 \times 10^{-3} \mathrm{~N} \mathrm{~m}^{-1} \mathrm{~K}^{-1}$ and $\beta=2.4 \times 10^{-2} 1 \mathrm{~mol}^{-1}$ from Moore et al. (2008). The organic mass fraction of marine aerosols in different modes is calculated by dividing marine POA by the total mass of dry aerosol components within each mode. Due to the overwhelming contribution of sea-salt, surfactant effects of supermicron marine POA aerosols are not considered in the simulations. Previous studies have revealed that Eq. (3) does not account for the possible partitioning of surface-active compounds between droplet surface and the bulk phase (Sorjamaa et al., 2004; Li et al., 2010). As neglecting such partitioning effects can potentially overestimate the surface tension depression, surfactant effects of marine organics treated this way should be viewed as a maximum effect on CCN number concentration.

\subsubsection{Aerosol activation parameterization}

A prognostic aerosol activation/droplet nucleation parameterization developed by Nenes and Seinfeld (2003) and updated by Fountoukis and Nenes (2005) (hereafter referred to as FN) and Barahona et al. (2010) has been implemented in CAM5. The FN parameterization is one of the most 
Table 2. Description of CAM5 sensitivity simulations.

\begin{tabular}{ll}
\hline Name & Emissions \\
\hline Default & $\mathrm{SO}_{2}, \mathrm{SO}_{4}^{2-}$, terrestrial POA, terrestrial SOA, BC, $\mathrm{NH}_{3}$, dust, DMS, sea-salt \\
SOA/MS & Same as Default but with marine SOA, MS \\
G11 & Same as Default but with Gantt et al. (2011) marine POA externally-mixed with sea-salt, marine SOA, MS \\
V10 & Same as Default but with Vignati et al. (2010) marine POA externally-mixed with sea-salt, marine $\mathrm{SOA}^{-} \mathrm{MS}^{-}$ \\
G11-Internal & Same as G11, except marine POA internally-mixed with sea-salt, no marine SOA or MS ${ }^{-}$ \\
V10-Internal & Same as V10, except marine POA internally-mixed with sea-salt, no marine SOA or MS \\
\hline
\end{tabular}

comprehensive cloud droplet activation mechanisms developed to date (Fountoukis and Nenes, 2005). In addition to treating the competition among all modes, the FN parameterization can also include the presence of surfactants and slightly soluble species (Shulman et al., 1996; Laaksonen et al., 1998). The FN parameterization includes a size-dependent mass transfer coefficient for the growth of water droplets to accommodate the effect of size (and potentially organic films) on the droplet growth rate. The FN parameterization gives similar results to a detailed numerical cloud parcel model with a substantially lower simulation time, and has been shown to accurately predict cloud droplet activation for a wide range of observational conditions for non-precipitating warm clouds of variable microphysics, aerosol composition, and size distribution (Nenes and Seinfeld, 2003; Meskhidze et al., 2005; Fountoukis et al., 2007; Ghan et al., 2011; Morales et al., 2011). The combination of accuracy and speed makes this parameterization appropriate for the calculation of the aerosol activation processes in GCMs. The FN parameterization can employ both sectional (binned) and modal (lognormal) representations of the aerosol size distribution and chemical composition. The modal version has been implemented in CAM5. As both the mass and number fractions activated for each mode are needed to determine the nucleation scavenging rate of aerosols in the model, the FN parameterization was modified by adding activated mass fraction calculation following Abdul-Razzak et al. (1998). Although, the FN parameterization enables variable accommodation coefficients, to be consistent with the rest of CAM5 model results employing AR-G, a mass accommodation coefficient of 1 is used in the simulations with the FN parameterization. Using two different state-of-the-art aerosol activation parameterizations gives a robust assessment of the extent to which ocean ecosystems can influence regional aerosol and cloud radiative properties.

\section{Simulation setup}

Table 2 lists the simulations carried out to study the effects of marine organic aerosol emissions on ambient aerosol concentration and $\mathrm{CCN}$ activity. All simulations are conducted for $5 \mathrm{yr}$ with a 3 month spin-up. All figures (except emission fluxes) show 5-yr averages. The CAM5 runs are carried out for three emissions schemes: "Default", "V10", and "G11". The Default simulation uses all the original options of CAM5, including the AR-G aerosol activation scheme and the baseline terrestrial and marine emissions. The baseline marine emissions in the model include sea-salt and DMS (with only yield of $\mathrm{SO}_{4}^{2-}$ ). The V10 simulation uses all the same options as the Default, with the addition of marine POA emissions following Vignati et al. (2010) and marine SOA/MS ${ }^{-}$production as described above. The G11 simulation is similar to the V10 but employs the Gantt et al. (2011) marine POA emissions. Therefore, the differences among the Default, V10, and G11 simulations can be attributed exclusively to the effects of marine POA and SOA (including $\mathrm{MS}^{-}$). Differences between V10 and G11 are due to differences in marine POA emission parameterizations. A number of sensitivity studies are also carried out to examine how reasonable variations in the key parameters for marine organic aerosol affect the model-predicted CCN and cloud microphysics properties. The "V10-Internal" and "G11-Internal" simulations are intended to test the effects of mixing state of the marine POA emissions. In these two simulations, marine POA emissions are added to the aerosol modes as internallymixed with sea-salt and marine SOA and $\mathrm{MS}^{-}$production are not considered. In "SOA/MS" simulations, only marine SOA and $\mathrm{MS}^{-}$production (no marine POA emissions) are added to the Default scheme to study the contribution of these marine secondary aerosols to model-predicted effects of marine organic aerosols.

\section{Results}

\subsection{Marine emissions}

Table 3 lists simulated global annual emissions of compounds with marine sources. For both V10 and G11 simulations, the emission amounts of POA increase with larger aerosol sizes like that of sea-salt; however, relative to sea-salt the emissions of marine POA in the coarse mode are modest due to the progressively smaller organic enrichment of sea spray with size. The emission amounts of submicron marine 
Table 3. Annual mean global marine-source aerosol emissions and global burdens (units: $\mathrm{Tg}_{\mathrm{yr}}{ }^{-1}$ and $\mathrm{Tg}$ for emissions and burdens, respectively).

\begin{tabular}{|c|c|c|c|c|c|}
\hline Mode & $\begin{array}{l}\text { POA } \\
(\mathrm{V} 10)\end{array}$ & $\begin{array}{l}\text { POA } \\
\text { (G11) }\end{array}$ & $\mathrm{MS}^{-}$ & $\begin{array}{c}\text { SOA } \\
\text { (marine) }\end{array}$ & Sea-salt \\
\hline \multicolumn{6}{|l|}{ Emissions } \\
\hline Accumulation & 2.4 & 1.9 & & & 14.8 \\
\hline Aitken & 0.1 & 0.1 & & & 0.7 \\
\hline Fine sea-salt & 6.9 & 6.0 & & & 100.2 \\
\hline Submicron & 9.4 & 7.9 & & & 115.7 \\
\hline Coarse sea-salt & 23.0 & 18.6 & & & 3427.0 \\
\hline Total & 32.4 & 26.5 & 5.1 & 0.2 & 3542.8 \\
\hline \multicolumn{6}{|l|}{ Burden } \\
\hline Accumulation & 0.012 & 0.011 & & & 0.075 \\
\hline Aitken & 0.000 & 0.000 & & & 0.001 \\
\hline Fine sea-salt & 0.036 & 0.036 & & & 0.547 \\
\hline Submicron & 0.047 & 0.047 & & & 0.623 \\
\hline Coarse sea-salt & 0.031 & 0.032 & & & 4.903 \\
\hline Total & 0.078 & 0.079 & 0.021 & 0.002 & 5.526 \\
\hline
\end{tabular}

POA estimated using the two parameterizations in this study are $9.4 \mathrm{Tg} \mathrm{yr}^{-1}$ in the $\mathrm{V} 10$ simulation and $7.9 \mathrm{Tg} \mathrm{yr}^{-1}$ in the G11 simulation. Note that the size dependent scheme of OM $_{\text {SSA }}$ supplemented to the Vignati et al. (2010) parameterization had an overall minor effect on the absolute amount of submicron marine organic aerosol emissions (cf. 8.2 and $7-8 \mathrm{Tg} \mathrm{yr}^{-1}$ reported by Vignati et al. (2010) and Myriokefalitakis et al. (2010), respectively). This is somewhat unexpected, as the Marrtensson et al. (2003) emission function (used in CAM5) predicts a factor of five higher emission of submicron sea-salt mass, as compared to the Gong et al. (2003) function (used in Vignati et al., 2010). The lower than expected emissions of POA in the V10 simulations can be explained by the size-dependent $\mathrm{OM}_{\mathrm{SSA}}$ enrichment mechanism (with lower organic enrichments for larger sized submicron mode particles) applied to the Vignati et al. (2010) formulation. As the submicron sea spray mass is typically weighted toward the larger sizes (O'Dowd et al., 1997), the reduction of OMSSA with aerosol size yields lower marine POA mass emissions. The coarse mode contributes $\sim 70 \%$ of the total marine POA mass for both V10 and G11, but it is expected to have little climatic impact as it represents $<1 \%$ of coarse mode sea-salt mass emissions.

Although relatively similar in the magnitude of global emissions, the V10 and G11 parameterizations predict considerably different spatial distributions. Figure $1 \mathrm{a}$ and $\mathrm{b}$ show that over the mid- and high-latitude oceans $\left(30-90^{\circ} \mathrm{N}\right.$ and $30-90^{\circ} \mathrm{S}$ ), the annual average global emissions of submicron
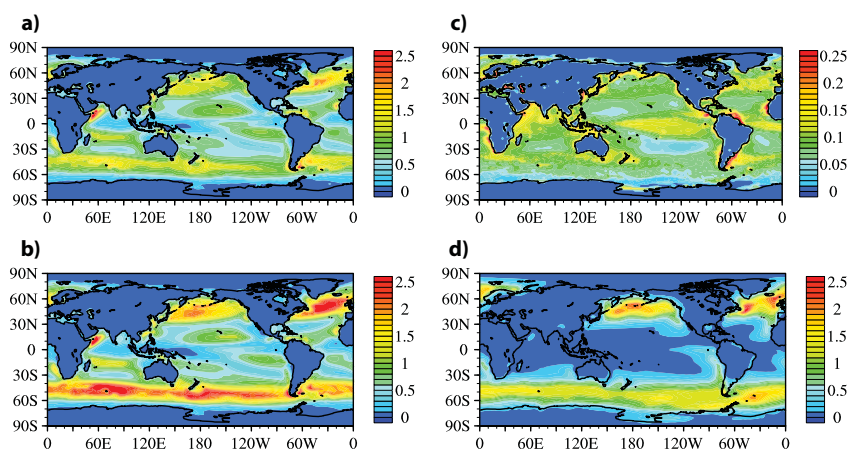

Fig. 1. Annual average global emissions of marine POA for the (a) G11 and (b) V10 simulations, (c) marine SOA, and (d) $\mathrm{MS}^{-}$in units of $\mathrm{ng} \mathrm{m}^{-2} \mathrm{~s}^{-1}$.

marine POA from the G11 simulation are lower than those of V10, while over the most of the tropical oceans $\left(30^{\circ} \mathrm{N}\right.$ to $\left.30^{\circ} \mathrm{S}\right) \mathrm{G} 11$ predicts higher emissions as compared to V10. The distributions of SOA and $\mathrm{MS}^{-}$, shown in Fig. 1c and $\mathrm{d}$, are different compared to that of POA in both magnitude and spatial distribution. For SOA, the magnitude of emissions is much lower than that of POA and the emissions are concentrated over the coastal upwelling regions characterized by high productivity. The magnitude of the $\mathrm{MS}^{-}$emissions is comparable to that of POA but is more focused in the high latitude oceans due to the high DMS flux and negative temperature dependence of the $\mathrm{MS}^{-}$yields (e.g. Bates et al., 1994; Kettle et al., 1999; Barnes et al., 2006).

\subsection{Marine organic aerosol mass concentrations}

The differences in the POA emission rates for the G11 and V10 simulations (Fig. 1a and b) lead to differences in the surface POA concentrations as shown in Fig. 2a and b. The largest differences in surface concentrations of marine organic aerosols for G11 and V10 simulations occur over the Southern Ocean, where G11 predicts substantially lower concentrations (up to $100 \mathrm{ng} \mathrm{m}^{-3}$ ) compared to V10 (up to $200 \mathrm{ng} \mathrm{m}^{-3}$ ) due to the stronger wind speed dependence of the V10 emission scheme and high wind speeds throughout the region. In the tropical Pacific, where wind speeds are much lower, G11 shows elevated concentrations relative to that of V10 due to its higher emissions rate there. Overall, the G11 simulation produces relatively uniform surface concentrations with values greater than $50 \mathrm{ng} \mathrm{m}^{-3}$ of marine organic aerosols over most of the oceanic regions. In addition to the emissions, surface layer POA concentrations are also influenced by the differences in transport and deposition patterns. Comparison of Figs. 1a and 2a shows that although the high concentrations are typically co-located with the regions of high emissions, the oceanic areas with low annual precipitation (e.g. tropical oceans on both sides of the Intertropical Convergence Zone) tend to have elevated concentrations 
relative to their emission rates. Figure $2 \mathrm{a}$ and $\mathrm{b}$ show that over most of the oceanic regions, surface concentrations of submicron marine POA are between $50-200 \mathrm{ng} \mathrm{m}^{-3}$ (with maximum of $250 \mathrm{ng} \mathrm{m}^{-3}$ ), which are slightly lower than the values of $100-500 \mathrm{ng} \mathrm{m}^{-3}$ reported in previous observational and modeling studies (Sciare et al., 2009; Russell et al., 2010, 2011; Gantt et al., 2010). Potential reasons for the model underestimation include the climatological surface ocean [chla] used in both V10 and G11 emission parameterizations, the annual averaging of the emissions, and the coarse horizontal resolution of the model that may not capture local point observations. The assumption of a single value of 1.4 for the organic aerosol to organic carbon (OC) mass ratio (Decesari et al., 2007; Facchini et al., 2008b) is also likely to be a source of uncertainty. In terms of total marine-source submicron $\mathrm{OM}\left(\mathrm{OM}=\mathrm{POA}+\mathrm{SOA}+\mathrm{MS}^{-}\right)$concentrations, Fig. $2 \mathrm{c}$ shows that widespread areas over productive waters of the Northern Atlantic, Northern Pacific, and the Southern Ocean have marine-source submicron OM surface concentrations of $100 \mathrm{ng} \mathrm{m}^{-3}$ with values over $400 \mathrm{ng} \mathrm{m}^{-3}$ in the most productive areas.

Global climate models like CAM5 give an average realization of the atmospheric state and therefore should not be directly compared to the measurements conducted for a short period of time at specific locations. This puts a strict constraint on observational data suitable for model validation. On Fig. 2c the model components of OM (POA, SOA, and $\mathrm{MS}^{-}$) are compared to long-term monthly-average observations of water insoluble organic matter (WIOM), water soluble organic matter (WSOM), and $\mathrm{MS}^{-}$at two coastal sites: Mace Head and Amsterdam Island (Sciare et al., 2009). It is commonly assumed that WIOM over the marine environment is predominantly associated with primary emissions from the sea surface, while WSOM is of secondary origin (Ceburnis et al., 2008; Facchini et al., 2008b). However, recent studies revealed that oxidation of marine primary $\mathrm{OM}$ could also lead to the formation of WSOM (Rinaldi et al., 2010; Ovadnevaite et al., 2011). This process is not included in our model simulations and could lead to underestimation of ocean derived WSOM. Long-term observations of marine organic aerosols available from these two sites smooth out day-to-day variations and therefore are suitable for judging the accuracy of the CAM5 predicted organic aerosol concentrations over the remote marine regions. Figure $2 \mathrm{c}$ shows that at the Mace Head station located on the Atlantic coast of Ireland (Yoon et al., 2007) both the V10 and G11 simulations are roughly able to replicate the magnitude of ocean-derived WIOM for the periods of low biological activity (November through March). Figure $2 \mathrm{c}$ also highlights a significant underestimation of ocean-derived POA, particularly during the periods of high biological activity at Mace Head. Possible reasons for the model underestimation include the climatological monthly mean surface ocean [chl- $a$ ], coarse model grid averaging of wind speed and [chl- $a]$ over highly productive surface regions off the coast of Mace Head, small
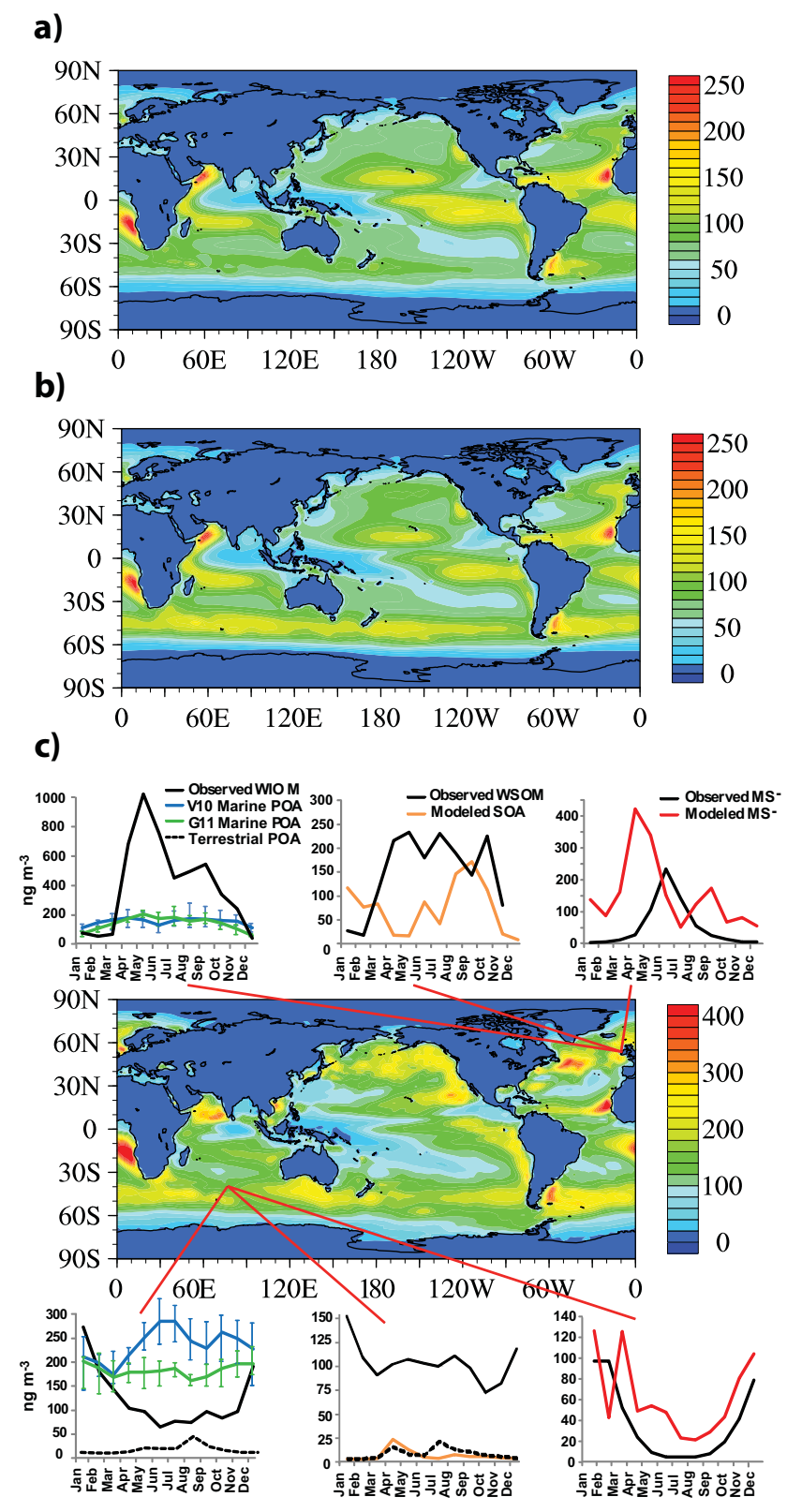

Fig. 2. Annual average submicron marine POA concentrations at the surface layer from the (a) G11 and (b) V10 simulations and (c) the total marine OM concentrations in units of $\mathrm{ng} \mathrm{m}^{-3}$ with the top and bottom charts comparing the monthly average concentrations of WIOM, WSOM, and $\mathrm{MS}^{-}$concentrations with the modeled POA (error bars are the maximum and minimum monthly averaged values during the 5-yr simulation period), $\mathrm{SOA}$ and $\mathrm{MS}^{-}$at Mace Head, Ireland and Amsterdam Island, respectively. Note that modeled terrestrial POA and SOA are not shown for Mace Head due to the selection of marine air masses for the observations.

but non-negligible ( $\sim 20 \%$ ) contribution of fossil fuel to OM classified as "marine" at Mace Head (Ceburnis et al., 2011), and uncertainties related to the surf zone impact on aerosol emissions (de Leeuw et al., 2000; Vignati et al., 2001). 
According to Fig. 2c, seasonal differences between the V10 and G11 schemes are predicted at Amsterdam Island, over the Southern Ocean. This figure shows that at Amsterdam Island the G11 scheme captures the seasonal variation of POA (more productive summer and less productive winter periods) slightly better than V10, although neither simulation accurately predicts the range of concentrations observed during the different seasons. Neglecting any potential non-emission related inadequacies in the model, the most likely reason for this problem is the strong wind speed dependence of the sea spray function employed by the two emission schemes. Although aerosol chemical composition over Amsterdam Island can be considered to be representative for marine background (Sciare et al., 2009), given an extreme paucity of ground-based long-term measurements of marine organic aerosols, it is difficult to assess the accuracy of either V10 or G11 emission mechanism on a global scale. More detailed studies using CAM5 with the reanalyzed winds (for comparison with daily observations) may be needed for improved evaluation of different emission mechanisms against larger suite of observational data. Nevertheless, Fig. 2c indicates that compared to simulations when only terrestrial emissions of POA are accounted for, the implementation of marine POA in CAM5 (either through V10 or G11 schemes) leads to an improvement (Default mean bias of $-106 \mathrm{ng} \mathrm{m}^{-3}$ vs. G11 mean bias of $69 \mathrm{ng} \mathrm{m}^{-3}$ ) in the predicted organic aerosol concentrations at Amsterdam Island. Figure 3 shows that in general, both G11 and V10 simulations display distinct seasonalities in $\mathrm{OM}$ mass concentrations over the wider Southern Ocean waters (roughly between $40^{\circ} \mathrm{S}$ to $70^{\circ} \mathrm{S}$ ) caused by variability in [chl- $a$ ] (large biological productivity during austral summer and low in winter). However, despite such similarities, Fig. 3 shows that due to stronger wind speed dependence, V10 is consistently predicting higher OM mass concentrations and less seasonal variability compared to G11.

Also shown in Fig. 2c is the observed monthly-average surface WSOM concentration at both sites which are well in excess of the modeled SOA concentrations. The underestimation of WSOM in CAM5 may be caused by several factors including an underestimation of phytoplankton emissions of isoprene and monoterpenes with the ratios of "top-down" to "bottom-up" estimates on the order of 30 and 2000, respectively (Luo and Yu, 2010), a lack of accounting for aged POA from marine sources that exhibit increased solubility (Rinaldi et al., 2010), or condensation of semi-volatile POA (Robinson et al., 2007) of possible marine origin. These model results are consistent with several recent studies suggesting that SOA produced from marine BVOCs may not be enough to explain the observed WSOM concentrations, especially over the Southern Ocean (Arnold et al., 2009; Claeys et al., 2009).

The spatial distribution of marine-source OM surface concentration for each of the three components (POA, SOA, and $\mathrm{MS}^{-}$) shown in Fig. 4 reveal distinct patterns over the global oceans: POA and to a lesser degree SOA are comprising the
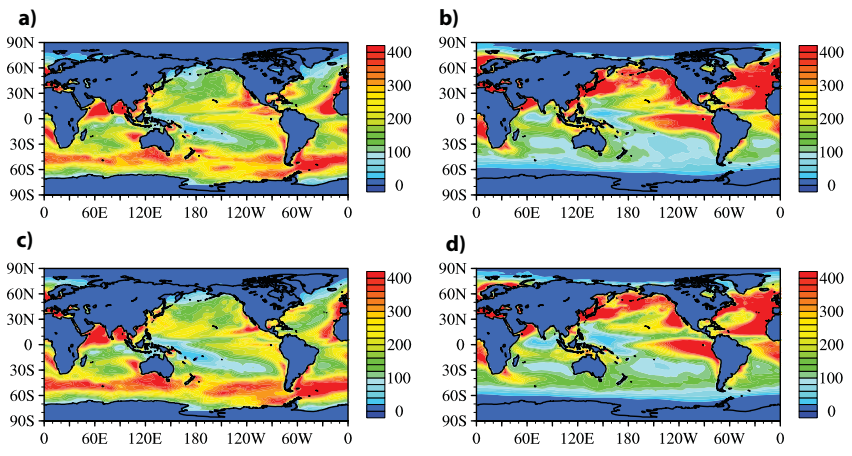

Fig. 3. Average submicron marine-source $O M$ concentrations at the surface in units of $\mathrm{ng} \mathrm{m}^{-3}$ for (a), (b) G11 and (c), (d) V10 for December-February (left column) and June-August (right column).

majority of tropical ocean OM mass while a combination of POA and $\mathrm{MS}^{-}$is making up the mid-latitude OM, with $\mathrm{MS}^{-}$dominating at high-latitudes. These results are similar to that of Myriokefalitakis et al. (2010), although POA contributes more to tropical OM in the G11 simulation due to the higher emissions/concentrations. Not shown is the contribution of each of the three components to submicron marine OC mass, which would be somewhat different owing to the distinct OM/OC ratios intrinsic to each type of OM. Marine POA, for example, would contribute substantially to global marine OC because of the assumed 1.4 OM/OC ratio (Decesari et al., 2007; Facchini et al., 2008b) as compared to an $\mathrm{OM} / \mathrm{OC}$ ratio of $\sim 8$ for $\mathrm{MS}^{-}$.

\subsection{Changes in $\mathrm{CCN}$ concentration}

A number of studies (e.g. Lohmann et al., 1999, 2007; Takemura et al., 2005; Wang and Penner, 2009; Hoose et al., 2009) highlight the challenges for GCMs to accurately represent the seeds of cloud droplets over pristine remote oceanic regions. To evaluate the representativeness of the modelpredicted marine organic aerosols to serve as $\mathrm{CCN}$ over remote marine regions, we compare CAM5 simulated surface CCN concentration $(S=0.2 \%)$ with observations from several field campaigns. A supersaturation of $0.2 \%$ is selected to be representative of an average effective supersaturation in marine boundary-layer stratocumulus clouds, while the choice of the first model layer allows our results to be consistent with the above discussion of marine organic aerosol distribution over the ocean. Figure 5a shows that when marine organic aerosols are assumed to be externally-mixed with sea-salt (the G11 simulation), the greatest percentage changes $(\sim 20 \%)$ in the surface $\mathrm{CCN}$ occur in the vicinity of biologically productive ocean waters. The results of the paired $\mathrm{t}$-test $(P<0.05)$ between marine-source submicron $\mathrm{OM}$ concentration and $\mathrm{CCN}$ number changes show that the regional increases in $\mathrm{CCN}$ in the vicinity of biologically active regions are statistically significant (see Fig. S1 


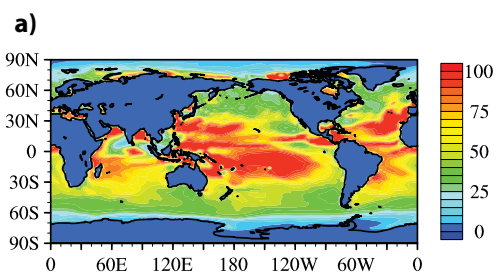

b)
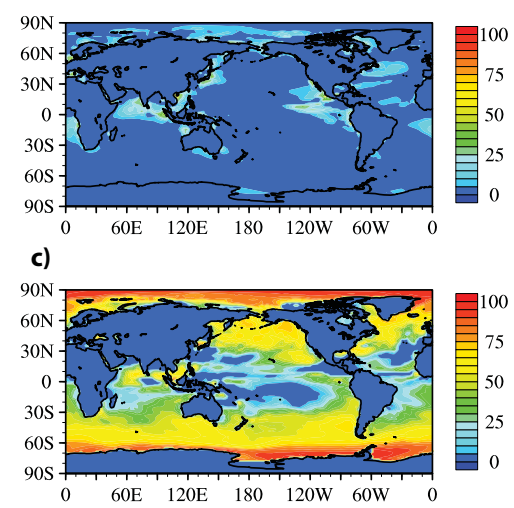

Fig. 4. Relative percentage contribution of (a) POA (b) SOA, and (c) $\mathrm{MS}^{-}$to average surface level marine-source submicron OM mass concentration from the G11 simulation.

in Suupplement). A similar spatial distribution and sign of these changes, albeit at different magnitudes, is predicted for $\mathrm{CCN}$ concentration at supersaturations of $0.01 \%$ and $1 \%$ (see Fig. S2 in Supplement). Vertical profiles of modelpredicted and observed $\mathrm{CCN}$ have been compared by selecting the collocated CAM5 grid cell and simulated month(s) closest to that of each campaign. The detailed description of the location and dates for each of the field experiments can be found elsewhere (e.g. Ghan et al., 2001 and references therein; Wang et al., 2008, 2010). When compared to observed CCN concentrations $(S=0.2 \%)$ from various field campaigns (vertical plots on Fig. 5a), it can be seen that for the selected measurement locations, marine organic aerosols have a minor effect on model-predicted CCN. Figure 5a shows that all model-predicted vertical profiles of CCN concentration decrease with height, except FIRE3 where simulation profiles are nearly invariant with height. The agreement between simulated and observed profiles is within the range of variability in the observations. Deviations of modelpredicted CCN from the observations (e.g. for SOCEX1) were previously attributed to a combination of factors including excessive $\mathrm{MS}^{-}$and inefficient wet removal in the model (Ghan et al., 2001).

Comparison of Fig. 5a and b shows that the surface CCN concentration changes are similar between the G11 and V10 simulations (with the exception of the Southern Ocean which had a greater increase in the V10 simulation). These figures show that over most of the oceans, marine-source organic aerosols increase surface $\mathrm{CCN}$ concentration by less than $10 \%$. Inspection of Fig. 5 also reveals reduction of $\mathrm{CCN}$ con-

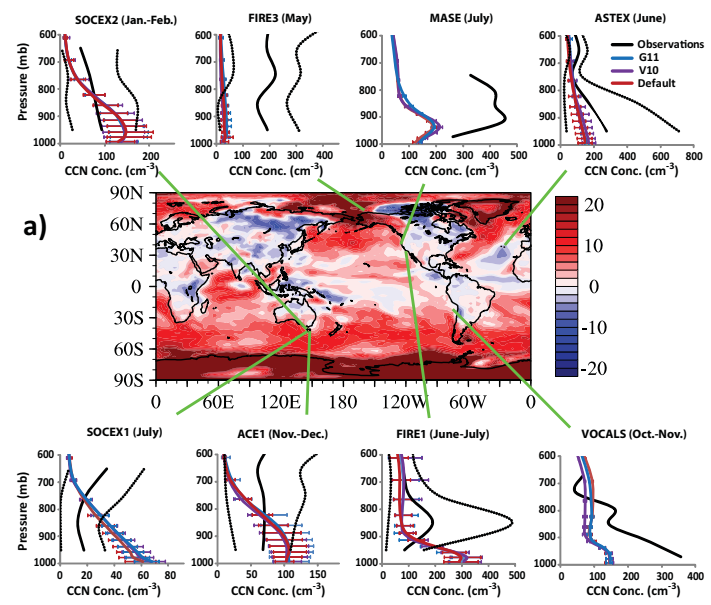

b)

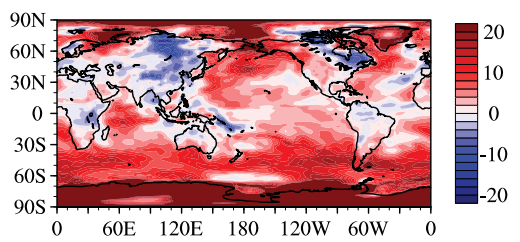

Fig. 5. Annual average percentage change in surface $\mathrm{CCN}$ concentration at $0.2 \%$ supersaturation between the Default and (a) G11 and (b) V10 simulations. The inserts with charts are comparing the observed vertical distribution of $\mathrm{CCN}(0.2 \%)$ from various remote ocean and coastal field campaigns (solid black line represents the mean concentration and dotted lines represent the upper and lower 10 percentile) with the Default, V10, and G11 simulations (solid lines are mean concentrations and error bars are the maximum and minimum monthly averaged values during the 5-yr simulation period).

centration for most of the land regions (sometimes far inland over the Europe and North America), although such changes do not seem to be statistically significant (see Fig. S1 in Supplement). Our data analysis (shown in Table 4) indicates that for all the simulations examined, changes in globallyaveraged surface $\mathrm{CCN}$ concentration due to marine organic aerosols have different signs over the land and the ocean. The CAM5 is a coupled aerosol/climate model that solves the three dimensional conservation equations for meteorological fields and includes physically-based treatment of aerosols and clouds. Therefore, it is plausible that the reduction in $\mathrm{CCN}$ number concentration over the land, thousands of kilometers away from the emission sources, is caused by marinesource organic aerosol-induced changes to meteorology and cloud microphysical processes. This hypothesis will be explored in detail in the second part of this study which examines the spatially heterogeneous climate forcing by marine organic aerosol. Overall, Fig. 5 shows that the effects of marine organic aerosol are likely to be global and not merely limited to oceanic regions.

The spatial variations of percentage change in surface $\mathrm{CCN}$ number concentration due to marine organics are 


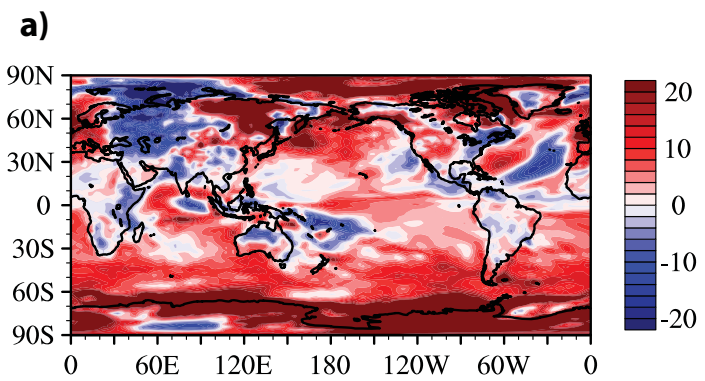

b)

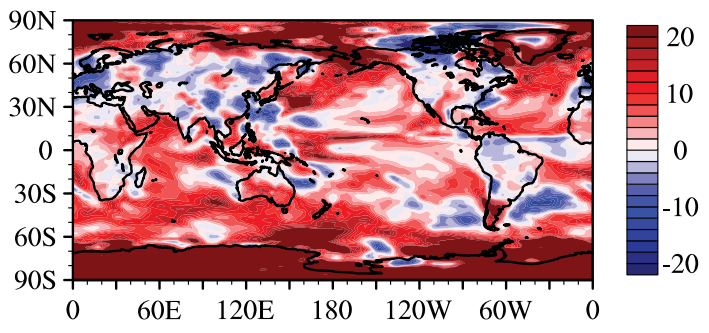

Fig. 6. Average percentage change in surface $\mathrm{CCN}(0.2 \%)$ concentration between the Default and G11 for (a) December-February and (b) June-August.

shown in Fig. 6. Despite marked seasonality in submicron marine OM mass concentration over productive waters of the Northern Pacific and Atlantic and the Southern Oceans (see Fig. 3), Fig. 6 shows modest seasonal modulation in percent change of $\mathrm{CCN}$ number. The main reason for this is likely to be the collocation of the strongest sources of marine organic aerosol and DMS, i.e. ocean regions with elevated primary productivity. As DMS is one of the main sources of CCN over the remote marine regions, Fig. 6 suggests that the contribution of marine organic aerosol to the $\mathrm{CCN}$ budget can be important throughout the whole year. Moreover, according to Eq. (1) the organic mass fraction of sea spray approaches $100 \%$ (pure organics) for particles below $100 \mathrm{~nm}$ in dry diameter, reflecting the highest potential enrichment in the organic fraction (Sellegri et al., 2006; Bigg and Leck, 2008; Hultin et al., 2010). Several studies using laboratorygenerated primary marine aerosol proposed that due to their low CCN activity sub-200 nm diameter organic particles are not expected to enhance the CCN budget over the oceans (Fuentes et al., 2011). However, Fig. 6 suggests that these submicron-sized marine POA could be of considerable importance to marine $\mathrm{CCN}$ budget even if they are emitted at a size below the critical diameter for droplet activation at supersaturations found in marine stratus clouds. Such organic particles could serve as nuclei for the growth of sulfate particles from the oxidation of DMS, providing an alternative mechanism to homogeneous nucleation of sulfate particles (Andreae and Rosenfeld, 2008). Table 5 shows that over the global ocean, mean particle number changes in different modes of aerosol size distribution are small.
Table 4. Model-predicted annual-mean surface CCN (at $0.2 \%$ supersaturation) concentrations (in $\mathrm{cm}^{-3}$ ).

\begin{tabular}{lrrrrr}
\hline & \multicolumn{2}{c}{ Global } & & \multicolumn{2}{c}{ Ocean } \\
\cline { 2 - 3 } \cline { 5 - 6 } Simulation & Average & $\begin{array}{c}\text { Difference } \\
\text { from Default }\end{array}$ & & Average & $\begin{array}{r}\text { Difference } \\
\text { from Default }\end{array}$ \\
\hline Default & 181.9 & & & 107.7 & \\
SOA/MS & 182.8 & +0.9 & & 108.8 & +1.1 \\
G11 & 184.5 & +2.6 & & 111.7 & +4.0 \\
V10 & 184.9 & +3.0 & & 112.3 & +4.6 \\
G11-Internal & 181.6 & -0.4 & & 107.4 & -0.4 \\
V10-Internal & 181.4 & -0.6 & & 107.9 & 0.2 \\
\hline
\end{tabular}

Table 5. Model-predicted annual-mean surface aerosol number concentrations (in $\mathrm{cm}^{-3}$ ) over the ocean for different aerosol modes examined in this study.

\begin{tabular}{lrrrr}
\hline Simulation & Accumulation & Aitken & $\begin{array}{c}\text { Fine } \\
\text { sea-salt }\end{array}$ & $\begin{array}{c}\text { Coarse } \\
\text { sea-salt }\end{array}$ \\
\hline Default & 122.1 & 206.5 & 4.2 & 0.9 \\
SOA/MS & 121.5 & 200.6 & 4.2 & 0.9 \\
G11 & 125.1 & 199.1 & 4.8 & 0.9 \\
V10 & 125.9 & 199.3 & 4.8 & 0.9 \\
G11-Internal & 121.9 & 203.6 & 4.3 & 0.9 \\
V10-Internal & 122.7 & 205.4 & 4.2 & 0.9 \\
\hline
\end{tabular}

The addition of marine SOA and $\mathrm{MS}^{-}$to the model did not make large differences in CCN concentration (see Fig. 7a and Table 4), except over the polar regions. The low sensitivity of $\mathrm{CCN}$ to the marine SOA at low and mid-latitudes indicates the limited influence of marine biogenic trace gases on the size distribution and chemical composition of the climatically-relevant accumulation mode aerosols (see Table 5). Overall, Figs. 5 and 7 suggest that different marine organic aerosol sources may influence $\mathrm{CCN}$ concentration in different regions; secondary aerosols increase $\mathrm{CCN}$ more in polar regions (primarily due to elevated emissions of DMS), while POA increases CCN concentrations by the greatest percentage in mid-latitude and tropical oceanic regions.

Figure $7 \mathrm{~b}$ and compare the percentage change in $\mathrm{CCN}$ concentration between the Default and the G11-Internal and V10-Internal simulations, respectively. These simulations do not include SOA and $\mathrm{MS}^{-}$production and marine POA emissions are added as internally-mixed with sea-salt. Figure $7 \mathrm{~b}$ and $\mathrm{c}$ show that for these two simulations the emission of internally-mixed marine POA provides diverse results with enhancement and reduction in surface $\mathrm{CCN}$ concentration relative to the Default. These figures show that when sea spray is treated as an internal mixture of marine organics and sea-salt (no change in number), the model predicts slight reduction in $\mathrm{CCN}$ concentration, even over the 
a)

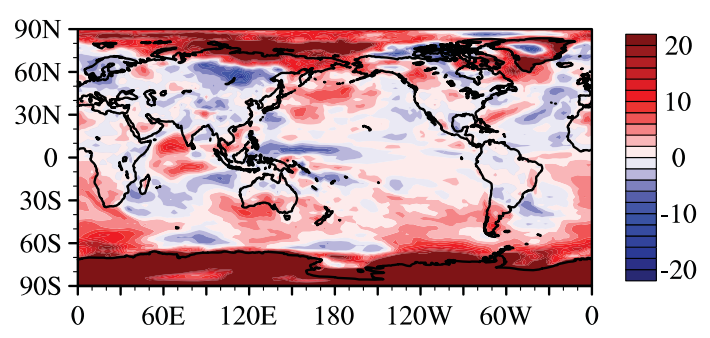

b)
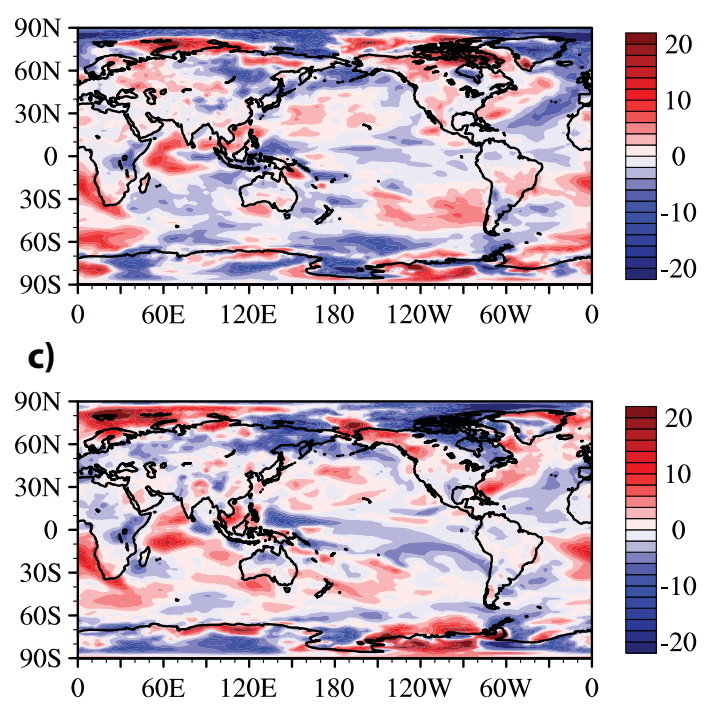

Fig. 7. Annual average percentage change in surface $\mathrm{CCN}$ concentration at $0.2 \%$ supersaturation between the Default and (a) SOA/MS ${ }^{-}$, (b) G11-Internal, and (c) V10-Internal.

highly productive waters of the southern ocean. The sign of the $\mathrm{CCN}$ change due to the addition of marine organics to sea-salt aerosol is determined by the relative significance of the increase in the mean modal diameter due to the addition of mass and the decrease in particle hygroscopicity. According to Table 4, the addition of internally-mixed marine organic aerosol yields a slight reduction in model-predicted global mean surface $\mathrm{CCN}$ concentration. As a supersaturation of $0.2 \%$ corresponds to sea-salt particles with dry diameters of $\sim 72 \mathrm{~nm}$, i.e. accumulation mode where ambient measurements show the largest increase in $\mathrm{CCN}$ number associated with biologically active regions (Bigg, 2007; Yoon et al., 2007; Rinaldi et al., 2010), treatment of marine POA emissions only as internal mixture is likely to underestimate their cloud microphysical and radiative effects. The large discrepancy in yearly-mean surface CCN concentration based on the assumption of mixing state of marine POA, ranging from up to a $20 \%$ increase to an anticipated decrease over productive waters, highlights the need for a better characterization of marine organic aerosol emission mechanisms and chemical composition.

\section{Conclusions}

Marine organic emissions are implemented in CAM5 by adding two different online emission parameterizations of marine POA and offline productions of marine SOA and $\mathrm{MS}^{-}$, derived from phytoplankton-emitted BVOCs. The estimated annual total submicron marine POA emissions are $9.4 \mathrm{Tg} \mathrm{yr}^{-1}$ and $7.9 \mathrm{Tg} \mathrm{yr}^{-1}$ using the Vignati et al. (2010) and Gantt et al. (2011) parameterizations, respectively. Over biologically productive surface ocean waters, modelpredicted concentrations of submicron marine-source $\mathrm{OM}$ are estimated to be up to $400 \mathrm{ng} \mathrm{m}^{-3}$. Marine POA contributes to the major fraction (up to $250 \mathrm{ng} \mathrm{m}^{-3}$ ) of the submicron organic aerosol mass over the tropical and midlatitude areas, while $\mathrm{MS}^{-}$is found to dominate in high latitude regions. Marine SOA from phytoplankton-derived isoprene and monoterpenes contributes to a relatively small fraction (up to 20\%) of the surface concentration of marinesource OM. Extreme scarcity of ground-based long-term measurements of marine organic aerosols does not allow effective evaluations of marine-source surface OM concentrations predicted by the Vignati et al. (2010) and Gantt et al. (2011) emission mechanisms. Nevertheless, comparisons of model-predicted marine-source POA concentrations with observations of WIOM at the Northern and Southern Hemispheric coastal sites show that the Gantt et al. (2011) emission parameterization yields a more accurate representation for the seasonal cycle of marine organic aerosol mass concentrations. Our model simulations show that, when only the terrestrial emissions of POA are accounted for, CAM5 significantly under-predicts organic aerosol mass concentration over the remote ocean. However, remaining differences (often more than a factor of 2) between measured and model-predicted submicron marine organic aerosol concentrations suggest that comprehensive analysis of different marine POA emission schemes, combined with long-term measurements of size-and composition-dependent production flux of sea spray aerosol, and process-based laboratory studies are needed to improve model simulations of marine organic aerosol.

Although the global model-predicted surface CCN (at a $S=0.2 \%$ ) concentration is shown to be relatively insensitive to the addition of marine organic aerosols, marine emissions of organics are shown to influence surface $\mathrm{CCN}$ concentration over the localized regions of the remote ocean. The largest increases (up to $20 \%$ ) in yearly-averaged CCN concentration are obtained over biologically productive ocean waters when marine organic aerosol is assumed to be externally mixed with sea-salt. The addition of internallymixed marine organics provides diverse results, often with reductions of $\mathrm{CCN}$ concentration over biologically productive parts of the ocean. Based on the experimental evidence for the increased $\mathrm{CCN}$ concentration during the periods of higher [chl- $a$ ] levels (e.g. O'Dowd et al., 2004; Yoon et al., 2007; Fuentes et al., 2010), our study suggests that it 
is unlikely that marine organic aerosols are emitted only as an internal mixture with sea-salt, without changing aerosol number. This study also indicates that externally-mixed marine organic aerosol could be of importance to the marine CCN budget, even if they, as originally produced, are below the critical diameter for droplet activation at the supersaturation of $0.2 \%$. Such particles could serve as nuclei for the growth of sulfate particles from the oxidation of marine biogenic DMS. Neglecting the effects of marine organic aerosols on CCN number concentrations in climate models could, therefore, lead to underestimation in shallow marine cloud droplet number concentration. Changes in cloud microphysics and climate forcing due to marine organic aerosols using multiple aerosol activation parameterizations, surfactant effect calculations, and hygroscopicity values are further explored in the second part of this study.

\section{Supplementary material related to this article is available online at: http://www.atmos-chem-phys.net/11/11689/2011/ acp-11-11689-2011-supplement.pdf.}

Acknowledgements. This research was supported by the Office of Science (BER), US Department of Energy, Grant No. DEFG02-08ER64508. BG is also supported by a NASA NESSF. AN acknowledges support from NASA ACMAP and NSF CAREER awards. We also acknowledge the US Department of Energy as part of the Atmospheric Radiation Measurement (now Atmospheric System Research) Climate Research Facility MASE and VOCALS field campaigns from which $\mathrm{CCN}$ data was used.

Edited by: D. Spracklen

\section{References}

Abdul-Razzak, H. and Ghan, S. J.: A parameterization of aerosol activation: 2. Multiple aerosol types, J. Geophys. Res., 105, 6837-6844, 2000.

Abdul-Razzak, H., Ghan, S. J., and Rivera-Carpio, C.: A parameterization of aerosol activation: 1. Single aerosol type, J. Geophys. Res., 103, 6123-6131, 1998.

Andreae, M. O.: Aerosols before pollution, Science, 315, 50-51, 2007

Andreae, M. O. and Rosenfeld, D.: Aerosol-cloud-precipitation interactions, Part 1, The nature and sources of cloud-active aerosols: Earth Science Reviews, 89, 13-41, 2008.

Arnold, S. R., Spracklen, D. V., Williams, J., Yassaa, N., Sciare, J., Bonsang, B., Gros, V., Peeken, I., Lewis, A. C., Alvain, S., and Moulin, C.: Evaluation of the global oceanic isoprene source and its impacts on marine organic carbon aerosol, Atmos. Chem. Phys., 9, 1253-1262, doi:10.5194/acp-9-1253-2009, 2009.

Barahona, D., West, R. E. L., Stier, P., Romakkaniemi, S., Kokkola, H., and Nenes, A.: Comprehensively accounting for the effect of giant $\mathrm{CCN}$ in cloud activation parameterizations, Atmos. Chem. Phys., 10, 2467-2473, doi:10.5194/acp-10-2467-2010, 2010.
Barnes, I., Hjorth, J., and Mihalopoulos, N.: Dimethyl sul?de and dimethyl sulfoxide and their oxidation in the atmosphere, Chem. Rev., 106, 940-975, 2006.

Barth, M. C., Rasch, P. J., Kiehl, J. T., Benkovitz, C. M., and Schwartz, S. E.: Sulfur chemistry in the National Center for Atmospheric Research Community Climate Model: Description, evaluation, features and sensitivity to aqueous chemistry, J. Geophys. Res., 105, 1387-1415, 2000.

Bates, T. S., Calhoun, J. A., and Quinn, P. K.: Variations in the concentration ratio of methane-sulfonate to sulfate in marine aerosol particles over the South Pacific Ocean, J. Geophys. Res., 97, 9859-9865, 1992.

Bates, T. S., Kiene, R. P., Wolfe, G. V., Matrai, P. A., Chavez, F. P., Buck, K. R., Blomquist, B. W., and Cuhel, R. L.: The cycling of sulfur in surface seawater of the northeast Pacific, J. Geophys. Res., 99, 7835-7843, doi:10.1029/93JC02782, 1994.

Bigg, E. K.: Sources, nature and influence on climate of marine airborne particles, Environ. Chem., 4, 155-161, doi:10.1071/EN07001, 2007.

Bigg, E. K. and Leck, C.: The composition of fragments of bubbles bursting at the ocean surface, J. Geophys. Res., 113, D11209, doi:10.1029/2007JD009078, 2008.

Binkowski, F. S. and Shankar, U.: The regional particulate matter model, 1, Model description and preliminary results, J. Geophys. Res., 100, 26191-26209, 1995.

Blanchard, D. C.: The electrification of the atmosphere by particles from bubbles in the sea, Prog. Oceanogr., 1, 71-202, 1963.

Blanchard, D. C. and Woodcock, A. H.: Bubble formation and modification in the sea and its meteorological significance, Tellus, 9, 145-158, 1957.

Bond, T. C., Bhardwaj, E., Dong, R., Jogani, R., Jung, S., Roden, C., Streets, D. G., and Trautmann, N. M.: Historical emissions of black and organic carbon aerosol from energy-related combustion, 1850-2000, Global Biogeochem. Cy., 21, GB2018, doi:10.1029/2006GB002840, 2007.

Bonsang, B., Polle, C., and Lambert, G.: Evidence for marine production of isoprene, Geophys. Res. Lett., 19, 1129-1132, 1992.

Boucher, O., Moulin, C., Belviso, S., Aumont, O., Bopp, L., Cosme, E., von Kuhlmann, R., Lawrence, M. G., Pham, M., Reddy, M. S., Sciare, J., and Venkataraman, C.: DMS atmospheric concentrations and sulphate aerosol indirect radiative forcing: a sensitivity study to the DMS source representation and oxidation, Atmos. Chem. Phys., 3, 49-65, doi:10.5194/acp-3-49-2003, 2003.

Campolongo, F., Saltelli, A., Jensen, N. R., Wilson, J., and Hjorth, J.: The role of multiphase chemistry in the oxidation of dimethylsulfide (DMS). A latitude dependent analysis, J. Atmos. Chem., 32, 327-356, 1999.

Cavalli, F., Facchini, M. C., Decesari, S., Mircea, M., Emblicia, L., Fuzzi, S., Ceburnis, D., Yoon, Y. J., O’Dowd, C. D., Putaud, J.P., and Dell'Acqua, A.: Advances in characterization of size resolved organic matter in marine aerosol over the North Atlantic, J. Geophys. Res., 109, D24215, doi:10.1029/2004JD005137, 2004.

Ceburnis, D., O’Dowd, C. D., Jennings, G. S., Facchini, M. C., Emblico, L., Decesari, S., Fuzzi, S., and Sakalys, J.: Marine aerosol chemistry gradients: elucidating primary and secondary processes and fluxes, Geophys. Res. Lett., 35, L07804, doi:10.1029/2008GL033462, 2008.

Ceburnis, D., Garbaras, A., Szidat, S., Rinaldi, M., Fahrni, S., Per- 
ron, N., Wacker, L., Leinert, S., Remeikis, V., Facchini, M. C., Prevot, A. S. H., Jennings, S. G., Ramonet, M., and O’Dowd, C. D.: Quantification of the carbonaceous matter origin in submicron marine aerosol by ${ }^{13} \mathrm{C}$ and ${ }^{14} \mathrm{C}$ isotope analysis, Atmos. Chem. Phys., 11, 8593-8606, doi:10.5194/acp-11-8593-2011, 2011.

Chin, M., Rood, R. B., Lin, S.-J., Muller, J.-F., and Thompson, A. M.: Atmospheric sulfur cycle simulated in the global model GOCART: Model description and global properties, J. Geophys. Res., 105, 24671-24687, 2000.

Claeys, M. B., Wang, W., Vermeylen, R., Kourtchev, I., Chi, X., Farhat, Y. J., Surratt, D., Gómez-González, Y., Sciare, J., and Maenhaut, W.: Chemical characterisation of marine aerosol at Amsterdam Island during the austral summer of 2006-2007, J. Aerosol. Sci., 41, 13-22, doi:10.1016/j.jaerosci.2009.08.003, 2009.

Clarke, A. D., Owens, S., and Zhou, J.: An ultrafine seasalt flux from breaking waves: Implications for $\mathrm{CCN}$ in the remote marine atmosphere, J. Geophys. Res.-Atmos., 111, D06202, doi:10.1029/2005JD006565, 2006.

de Leeuw, G., Neele, F. P., Hill, M., Smith, M. H., and Vignati, E.: Production of sea spray aerosol in the surf zone, J. Geophys. Res., 105, 29397-29409, 2000.

Decesari, S., Facchini, M. C., Mircea, M., Cavalli, F., Emblico, L., Fuzzi, S., Moretti, F., and Tagliavini, E.: Source attribution of water-soluble organic aerosol by nuclear magnetic resonance spectroscopy, Environ. Sci. Technol., 41, 2479-2484, 2007.

Dentener, F., Kinne, S., Bond, T., Boucher, O., Cofala, J., Generoso, S., Ginoux, P., Gong, S., Hoelzemann, J. J., Ito, A., Marelli, L., Penner, J. E., Putaud, J.-P., Textor, C., Schulz, M., van der Werf, G. R., and Wilson, J.: Emissions of primary aerosol and precursor gases in the years 2000 and 1750 prescribed data-sets for AeroCom, Atmos. Chem. Phys., 6, 4321-4344, doi:10.5194/acp6-4321-2006, 2006.

Easter, R. C., Ghan, S. J., Zhang, Y., Saylor, R. D., Chapman, E., Laulainen, N. S., Abdul-Razzak, H., Leung, L. R., Bian, X., and Zaveri, R. A.: MIRAGE: Model description and evaluation of aerosols and trace gases, J. Geophys. Res., 109, D20210, doi:10.1029/2004JD004571, 2004.

Ellison, G. B., Tuck, A. F., and Vaida, V.: Atmospheric processing of organic aerosols, J. Geophys. Res., 104, 11633-11641, 1999.

Facchini, M. C., Decesari, S., Rinaldi, M., Carbone, C., Finessi, E., Mircea, M., Fuzzi, S., Moretti, F., Tagliavini, E., Ceburnis, D., O'Dowd, C. D.: Important source of marine secondary organic aerosol from biogenic amines, Environ. Sci. Technol., 42, 91169121, 2008a.

Facchini, M. C., Rinaldi, M., Decesari, S., Carbone, C., Finessi, E., Mircea, M., Fuzzi, S., Ceburnis, D., Flanagan, R., Nilsson, D., de Leeuw, G., Martino, M., Woeltjen, J., and O'Dowd, C. D.: Primary sub-micron marine aerosol dominated by insoluble organic colloids and aggregates, Geophys. Res. Lett., 35, L17814, doi:10.1029/2008GL034210, 2008b.

Fountoukis, C. and Nenes, A.: Continued development of a cloud droplet formation parameterization for global climate models, J. Geophys. Res., 110, D11212, doi:10.1029/2004JD005591, 2005.

Fountoukis, C., Nenes, A., Meskhidze, N., Bahreini, R., Brechtel, F., Conant, W., Jonsson, H., Murphy, S., Sorooshian, A., Varutbangkul, V., Flagan, R., and Seinfeld, J.: Aerosol - cloud drop concentration closure for clouds sampled during ICARTT,
J. Geophys. Res., 112, D10S30, doi:10.1029/2006JD007272, 2007.

Fuentes, E., Coe, H., Green, D., de Leeuw, G., and McFiggans, G.: On the impacts of phytoplankton-derived organic matter on the properties of the primary marine aerosol - Part 1: Source fluxes, Atmos. Chem. Phys., 10, 9295-9317, doi:10.5194/acp-10-92952010, 2010.

Fuentes, E., Coe, H., Green, D., and McFiggans, G.: On the impacts of phytoplankton-derived organic matter on the properties of the primary marine aerosol - Part 2: Composition, hygroscopicity and cloud condensation activity, Atmos. Chem. Phys., 11, 25852602, doi:10.5194/acp-11-2585-2011, 2011.

Gantt, B., Meskhidze, N., and Kamykowski, D.: A new physically-based quantification of marine isoprene and primary organic aerosol emissions, Atmos. Chem. Phys., 9, 4915-4927, doi:10.5194/acp-9-4915-2009, 2009.

Gantt, B., Meskhidze, N., and Carlton, A. G.: The contribution of marine organics to the air quality of the western United States, Atmos. Chem. Phys., 10, 7415-7423, doi:10.5194/acp-10-74152010, 2010.

Gantt, B., Meskhidze, N., Facchini, M. C., Rinaldi, M., Ceburnis, D., and O'Dowd, C. D.: Wind speed dependent size-resolved parameterization for the organic mass fraction of sea spray aerosol, Atmos. Chem. Phys., 11, 8777-8790, doi:10.5194/acp-11-87772011, 2011.

Geever, M., O’Dowd, C. D., van Ekeren, S., Flanagan, R., Nilsson, E. D., de Leeuw, G., and Rannik, U.: Submicron sea spray fluxes, Geophys. Res. Lett., 32, L15810, doi:10.1029/2005GL023081, 2005.

Ghan, S. J. and Zaveri, R. A.: Parameterization of optical properties for hydrated internally mixed aerosol, J. Geophys. Res., 112, D10201, doi:10.1029/2006JD007927, 2007.

Ghan, S. J., Guzman, G., and Abdul-Razzak, H.: Competition between sea-salt and sulfate particles as cloud condensation nuclei, J. Atmos. Sci., 55, 3340-3347, 1998.

Ghan, S. J., Easter, R. C., Hudson, J., and Bréon, F.-M.: Evaluation of aerosol indirect radiative forcing in MIRAGE, J. Geophys. Res., 106, 5317-5334, 2001.

Ghan, S. J., Abdul-Razzak, H., Nenes, A., Ming, Y., Liu, X., Ovchinnikov, M., Shipway, B., Meskhidze, N., Xu, J., and Shi, $\mathrm{X}$.: Droplet nucleation: Physically-based parameterizations and comparative evaluation, Journal of Advances in Modeling of Earth Systems, J. Adv. Model. Earth Syst., 3, M10001, 33 pp., doi:10.1029/2011MS000074, 2011.

Gong, S. L.: A parameterization of sea-salt aerosol source function for sub- and super- micron particles, Global Biogeochem. Cy., 17, 1097, doi:1029/2003GB002079, 2003.

Hawkins, L. N. and Russell, L. M.: Polysaccharides, proteins, and phytoplankton fragments: four chemically distinct types of marine primary organic aerosol classified by single particle spectromicroscopy, Advances in Meteorology, 2010, 612132, doi:10.1155/2010/612132, 2010.

Hoose, C., Kristjánsson, J. E., Iversen, T., Kirkevåg, A., Seland, Ø., and Gettelman, A.: Constraining cloud droplet number concentration in GCMs suppresses the aerosol indirect effect, Geophys. Res. Lett., 36, L12807, doi:10.1029/2009GL038568, 2009.

Horowitz, L. W., Walters, S., Mauzerall, D. L., Emmons, L. K., Rasch, P. J., Garnier, C., Tie, X., Lamarque, J.-F., Schultz, M. G., Tyndall, G. S., Orlando, J. J., and Brasseur, G. P.: A global 
simulation of tropospheric ozone and related tracers: Description and evaluation of MOZART, version 2, J. Geophys. Res., 108, 4728, doi:10.1029/2002JD002853, 2003.

Hultin, K. A. H., Nilsson, E. D., Krejci, R., Mårtensson, E. M., Ehn, M., Hagström, Å., and de Leeuw, G.: In situ laboratory sea spray production during the Marine Aerosol Production 2006 cruise on the northeastern Atlantic Ocean, J. Geophys. Res., 115, D06201, doi:10.1029/2009JD012522, 2010.

IPCC: The Physical Science Basis, in: Contribution of Working Group I of the Fourth Assessment Report of the Intergovernmental Panel on Climate Change, Cambridge University Press, Cambridge, UK, 2007.

Junker, C. and Liousse, C.: A global emission inventory of carbonaceous aerosol from historic records of fossil fuel and biofuel consumption for the period 18601997, Atmos. Chem. Phys., 8, 1195-1207, doi:10.5194/acp-8-1195-2008, 2008.

Kettle, A. J., Andreae, M. O., Amouroux, D., Andreae, T. W., Bates, T. S., Berresheim, H., Bingemer, H., Boniforti, R., Curran, M. A. J., DiTullio, G. R., Helas, G., Jones, G. B., Keller, M. D., Kiene, R. P., Leck, C., Levasseur, M., Malin, G., Maspero, M., Matrai, P., McTaggart, A. R., Mihalopoulos, N., Nguyen, B. C., Novo, A., Putaud, J. P., Rapsomanikis, S., Roberts, G., Schebeske, G., Sharma, S., Simó, R., Staubes, R., Turner, S., and Uher, G.: A global database of sea surface dimethylsulfide (DMS) measurements and a procedure to predict sea surface DMS as a function of latitude, longitude, and month, Global Biogeochem. Cy., 13, 399-444, 1999.

Kirkevåg, A., Iversen, T., Seland, Ø, Debernard, J. B., Storelvmo, T., and Kristjánsson, J. E: Aerosol-cloud-climate interactions in the climate model CAM-Oslo, Tellus A, 60, 492-512, 2008.

Klein, S. A. and Hartmann, D. L.: The seasonal cycle of low stratiform clouds, J. Climate, 6, 1587-1606, 1993.

Laaksonen, A., Korhonen, P., Kulmala, M., and Charlson, R. J.: Modification of the Kohler equation to include soluble trace gases and slightly soluble substances, J. Atmos. Sci., 55, 853$862,1998$.

Lamarque, J.-F., Bond, T. C., Eyring, V., Granier, C., Heil, A., Klimont, Z., Lee, D., Liousse, C., Mieville, A., Owen, B., Schultz, M. G., Shindell, D., Smith, S. J., Stehfest, E., Van Aardenne, J., Cooper, O. R., Kainuma, M., Mahowald, N., McConnell, J. R., Naik, V., Riahi, K., and van Vuuren, D. P.: Historical (1850-2000) gridded anthropogenic and biomass burning emissions of reactive gases and aerosols: methodology and application, Atmos. Chem. Phys., 10, 7017-7039, doi:10.5194/acp10-7017-2010, 2010.

Langmuir, I.: The constitution and fundamental properties of solids and liquids. ii. liquids, Am. Chem. Soc., 39, 1848-1906, 1917.

Leck, C. and Bigg, E. K.: Source and evolution of the marine aerosol - A new perspective, Geophys. Res. Lett., 32, L19803, doi:10.1029/2005GL023651, 2005.

Leck, C. and Bigg, E. K.: A modified aerosol-cloud-climate feedback hypothesis, Environ. Chem., 4, 400-403, 2007.

Lee, A., Goldstein, A. H, Kroll, J. H., Ng, N. L., Varutbangkul, V., Flagan, R. C., and Seinfeld, J. H.: Gas-phase products and secondary aerosol yields from the photooxidation of 16 different terpenes, J. Geophys. Res., 111, D17305, doi:10.1029/2006JD007050, 2006.

Li, X., Hede, T., Tu, Y., Leck, C., and Ågren, H.: Surface-active cis-pinonic acid in atmospheric droplets: A molecular dynamics study, J. Phys. Chem. Lett., 1, 769-773, doi:10.1021/jz9004784, 2010.

Liu, X. and Wang, J.: How important is organic aerosol hygroscopicity to aerosol indirect forcing, Environ. Res. Lett., 5, 044010, doi:10.1088/1748-9326/5/4/044010, 2010.

Lohmann, U., Feichter, J., Chuang, C. C., and Penner, J. E.: Predicting the number of cloud droplets in the ECHAM GCM, J. Geophys. Res., 104, 9169-9198, 1999.

Lohmann, U., Stier, P., Hoose, C., Ferrachat, S., Kloster, S., Roeckner, E., and Zhang, J.: Cloud microphysics and aerosol indirect effects in the global climate model ECHAM5-HAM, Atmos. Chem. Phys., 7, 3425-3446, doi:10.5194/acp-7-3425-2007, 2007.

Luo, G. and Yu, F.: A numerical evaluation of global oceanic emissions of $\alpha$-pinene and isoprene, Atmos. Chem. Phys., 10, 20072015, doi:10.5194/acp-10-2007-2010, 2010.

Ma, X., von Salzen, K., and Li, J.: Modelling sea salt aerosol and its direct and indirect effects on climate, Atmos. Chem. Phys., 8 , 1311-1327, doi:10.5194/acp-8-1311-2008, 2008.

Mårtensson, E., Nilsson, E., Leeuw, G., Cohen, L., and Hansson, H.: Laboratory simulations and parameterization of the primary marine aerosol production, J. Geophys. Res.-Atmos., 108, 4297, doi:10.1029/2002JD002263, 2003.

Meskhidze, N. and Nenes, A.: Phytoplankton and cloudiness in the Southern Ocean, Science, 314, 1419-1423, doi:10.1126/science.1131779, 2006.

Meskhidze, N., Nenes, A., Conant, W., and Seinfeld, J.: Evaluation of a new cloud droplet activation parameterization with in situ data from CRYSTAL-FACE and CSTRIPE, J. Geophys. Res.Atmos., 110, D16202, doi:10.1029/2004JD005703, 2005.

Meskhidze, N., Xu, J., Gantt, B., Zhang, Y., Nenes, A., Ghan, S. J., Liu, X., Easter, R., and Zaveri, R.: Global distribution and climate forcing of marine organic aerosol 2. Effects on cloud properties and radiative forcing, in preparation, 2011.

Middlebrook, A. M., Murphy, D. M., and Thomson, D. S.: Observations of organic material in individual marine particles at Cape Grim during the First Aerosol Characterization Experiment (ACE1), J. Geophys. Res., 103, 16475, 16475-16483, doi:10.1029/97JD03719, 1998.

Monahan, E. C., Spiel, D. E., and Davidson, K. L.: A model of marine aerosol generation via whitecaps and wave disruption, in: Oceanic Whitecaps and their Role in Air-sea Exchange Processes, edited by: Monahan, E. C., MacNiocaill, G., Reidel, Dordrecht, The Netherlands, 167-174, 1986.

Moore, R. H., Ingall, E., Sorooshian, A., and Nenes, A.: Molar mass, surface tension and droplet growth kinetics of marine organics from measurement of CCN activity, Geophys. Res. Lett., 35, L07801, doi:10.1029/2008GL033350, 2008.

Morales, R., Nenes, A., Jonsson, H., Flagan, R. C., and Seinfeld, J. H.: Evaluation of a diabatic droplet activation parameterization using in-situ cloud data, J. Geophys. Res., 116, D15205, doi:10.1029/2010JD015324, 2011.

Murphy, D. M., Thomson, D. S., and Mahoney, M. J.: In situ measurements of organics, meteoritic material, mercury and other elements in aerosols at 5 to 19 kilometers, Science, 282, 16641668, 1998.

Myriokefalitakis, S., Vignati, E., Tsigaridis, K., Papadimas, C., Sciare, J., Mihalopoulos, N., Facchini, M. C., Rinaldi, M., Dentener, F. J., Ceburnis, D., Hatzianastasiou, N., O’Dowd, C. D., 
van Weele, M., and Kanakidou, M.: Global modeling of the oceanic source of organic aerosols, Advances in Meteorology, 2010, 939171, doi:10.1155/2010/939171, 2010.

Neale, R. B., Chen, C.-C., Gettelman, A., Lauritzen, P. H., Park, S., Williamson, D. L., Conley, A. J., Garcia, R., Kinnison, D., Lamarque, J.-F., Marsh, D., Mills, M., Smith, A. K., Tilmes, S., Vitt, F., Cameron-Smith, P., Collins, W. D., Iacono, M. J., Easter, R. C., Ghan, S. J., Liu, X., Rasch, P. J., and Taylor, M. A.: Description of the NCAR Community Atmosphere Model (CAM 5.0), NCAR/TN-???+STR, 2010.

Nenes, A. and Seinfeld, J. H.: Parameterization of cloud droplet formation in global climate models, J. Geophys. Res., 108, 4415, doi:10.1029/2002JD002911, 2003.

Nightingale, P., Malin, G., Law, C., Watson, A., Liss, P., Liddicoat, M., Boutin, J., and Upstill-Goddard, R.: In situ evaluation of airsea gas exchange parameterizations using novel conservative and volatile tracers, Global Biogeochem. Cy., 14, 373-387, 2000.

Novakov, T., Corrigan, C. E., Penner, J. E., Chuang, C. C., Rosario, O., and Mayel Bracero, O. L.: Organic aerosols in the Caribbean trade winds: A natural source?, J. Geophys. Res., 102, 2130723313, 1997.

O'Dowd, C. D. and de Leeuw, G.: Marine aerosol production: a review of the current knowledge, Phil. Trans. R. Soc. A, 365, 1753-1774, 2007.

O'Dowd, C. D., Lowe, J. A, and Smith, M. H.: Marine aerosol, sea-salt, and the marine sulphur cycle: A short review, Atmos. Environ., 31, 73-80, 1997.

O’Dowd, C. D., Facchini, M. C., Cavalli, F., Ceburnis, D., Mircea, M., Decesari, S., Fuzzi, S., Yoon, Y. J., and Putaud, J. P.: Biogenically driven organic contribution to marine aerosol, Nature, 431, 676-680, 2004.

O’Dowd, C. D., Langmann, B., Varghese, S., Scannell, C., Ceburnis, D., and Facchini, M. C.: A combined organic-inorganic sea-spray source function, Geophys. Res. Lett., 35, L01801, doi:10.1029/2007GL030331, 2008.

O'Reilly, J. E., Maritorena, S., Mitchell, B. G., Siegel, D. A., Carder, K. L., Garver, S. A., Kahru, M., and McClain, C.: Ocean color chlorophyll algorithms for SeaWiFS, J. Geophys. Res., 103, 24937-24953, 1998.

Ovadnevaite, J., O'Dowd, C., Dall'Osto, M., Ceburnis, D., Worsnop, D. R., and Berresheim, H.: Detecting high contributions of primary organic matter to marine aerosol: A case study, Geophys. Res. Lett., 38, L02807, doi:10.1029/2010GL046083, 2011.

Petters, M. D. and Kreidenweis, S. M.: A single parameter representation of hygroscopic growth and cloud condensation nucleus activity, Atmos. Chem. Phys., 7, 1961-1971, doi:10.5194/acp-71961-2007, 2007.

Pio, C. A., Legrand, M., Oliveira, T., Afonso, J., Santos, C., Caseiro, A., Fialho, P., Barata, F., Puxbaum, H., Sanchez-Ochoa, A., Kasper-Giebl, A., Gelencse'r, A., Preunkert, S., and Schock, M.: Climatology of aerosol composition (organic versus inorganic) at nonurban sites on a west-east transect across Europe, J. Geophys. Res., 112, D23S02, doi:10.1029/2006JD008038, 2007.

Platnick, S. and Twomey, S.: Determining the susceptibility of cloud albedo to changes in droplet concentration with the Advanced Very High Resolution Radiometer, J. Appl. Meteorol., 33, 334-347, 1994.
Putaud, J. P., Van Dingenen, R., Mangoni, M., Virkkula, A., Raes, F., Maring, H., Prospero, J. M., Swietlicki, E., Berg, O. H., Hillamo, R., and Makela, T.: Chemical mass closure and assessment of the origin of the submicron aerosol in the marine boundary layer and the free troposphere at Tenerife during ACE2, Tellus B, 52, 141-168, 2000.

Quinn, P. K., Coffman, D. J., Kapustin, V. N., Bates, T. S., and Covert, D. S.: Aerosol optical properties in the marine boundary layer during the First Aerosol Characterization Experiment (ACE-1) and the underlying chemical and physical aerosol properties, J. Geophys. Res., 103, 16547-16563, 1998.

Randall, D. A., Coakley Jr., J. A., Fairall, C. W., Kropfli, R. A., and Lenschow, D. H.: Outlook for research on subtropical marine stratocumulus clouds, B. Am. Meteorol. Soc., 65, 1290-1301, 1984.

Rasch, P. J., Barth, M. C., Kiehl, J. T., Schwartz, S. E., and Benkovitz, C. M.: A description of the global sulfur cycle and its controlling processes in the National Center for Atmospheric Research Community Climate Model, Version 3, J. Geophys. Res., 105, 1367-1385, 2000.

Rinaldi, M., Decesari, S., Finessi, E., Giulianelli, L., Carbone, C., Fuzzi, S., O’Dowd, C. D., Ceburnis, D., and Facchini, M. C.: Primary and secondary organic marine aerosol and oceanic biological activity: Recent results and new perspectives for future studies, Adv. Meteorol., 2010, 310682, doi:10.1155/2010/310682, 2010.

Rissman, T., Nenes, A., and Seinfeld, J. H.: Chemical amplification (or dampening) of the Twomey effect: Conditions derived from droplet activation theory, J. Atmos. Sci., 61, 919-930, 2004.

Robinson, A. L., Donahue, N. M., Shrivastava, M. K., Weitkamp, E. A., Sage, A. M., Grieshop, A. P., Lane, T. E., Pierce, J. R., and Pandis, S. N.: Rethinking organic aerosols: Semivolatile emissions and photochemical aging, Science, 315, 1259-1262, doi:10.1126/science.1133061, 2007.

Russell, L. M., Hawkins, L. N., Frossard, A. A., Quinn, P. K., and Bates, T. S.: Carbohydrate-like composition of submicron atmospheric particles and their production from ocean bubble bursting, P. Natl. Acad. Sci., 107, 6652-6657, doi:10.1073/pnas.0908905107, 2010.

Russell, L. M., Bahadur, R., and Ziemann, P. J.: Identifying organic aerosol sources by comparing functional group composition in chamber and atmospheric particles, P. Natl. Acad. Sci. USA., 108, 3516-3521, doi:10.1073/pnas.1006461108, 2011.

Sabolis, A.: Quantifying marine emissions of biogenic volatile organic compounds using laboratory measurements, field measurements and remote sensing data, Master's Thesis, NCSU, available at: http://www.lib.ncsu.edu/resolver/1840.16/6473, 2010.

Sciare, J., Favez, O., Sarda-Estève, R., Oikonomou, K., Cachier, H., and Kazan, V.: Long-term observations of carbonaceous aerosols in the Austral Ocean atmosphere: Evidence of a biogenic marine organic source, J. Geophys. Res., 114, D15302 doi:10.1029/2009JD011998, 2009.

Seinfeld, J. H. and Pandis, S. N.: Atmospheric Chemistry and Physics: From Air Pollution to Climate Change (2nd edition), John Wiley \& Sons, 2006.

Sellegri, K., O’Dowd, C. D., Yoon, Y. J., Jennings, S. G., and de Leeuw, G.: Surfactants and submicron sea spray generation, J. Geophys. Res., 111, D22215, doi:10.1029/2005JD006658, 2006. Shaw, S. L., Chisholm, S. W., and Prinn, R. G.: Isoprene production 
by Prochlorococcus, a marine cyanobacterium, and other phytoplankton, Mar. Chem., 80, 227-245, 2003.

Shaw, S. L., Gantt, B., and Meskhidze, N.: Marine isoprene and monoterpene production and emissions: A review, Advances in Meteorology, 2010, 408696, doi:10.1155/2010/408696, 2010.

Shulman, M. L., Jacobson, M. C., Carlson, R. J., Synovec, R. E., and Young, T. E.: Dissolution behavior and surface tension effects of organic compounds in nucleating cloud droplets, Geophys. Res. Lett., 23, 277-280, doi:10.1029/95GL03810, 1996.

Smith, M. H.: Sea-salt particles and the CLAW hypothesis, Environ. Chem., 4, 391-395, doi:10.1071/EN07071, 2007.

Sorjamaa, R., Svenningsson, B., Raatikainen, T., Henning, S., Bilde, M., and Laaksonen, A.: The role of surfactants in Köhler theory reconsidered, Atmos. Chem. Phys., 4, 2107-2117, doi:10.5194/acp-4-2107-2004, 2004.

Stevens, B., Vali, G., Comstock, K., Wood, R., VanZanten, M., Austin, P. H., Bretherton, C. S., and Lenschow, D. H.: Pockets of Open Cells (POCs) and Drizzle in Marine Stratocumulus, B. Am. Meteorol. Soc., 86, 51-57, 2005.

Surratt, J. D., Chan, A. W. H., Eddingsaas, N. C., Chan, M. N., Loza, C. L., Kwan, A. J., Hersey, S. P., Flagan, R. C., Wennberg, P. O., and Seinfeld, J. H.: Reactive intermediates revealed in secondary organic aerosol formation from isoprene, P. Natl. Acad. Sci., 107, 6640-6645, doi:10.1073/pnas.0911114107, 2010.

Takemura, T., Nozawa, T., Emori, S., Nakajima, T., and Nakajima, T.: Simulation of climate response to aerosol direct and indirect effects with aerosol transport-radiation model, J. Geophys. Res., 110, D02202, doi:10.1029/2004JD005029, 2005.

Tyree, C. A., Hellion, V. M., Alexandrova, O. A., and Allen, J. O.: Foam droplets generated from natural and artificial seawaters, J. Geophys. Res., 112, D12204, doi:10.1029/2006JD007729, 2007.

Vignati, E., de Leeuw, G., and Berkowicz, R.: Modeling coastal aerosol transport and effects of surf-produced aerosols on processes in the marine atmospheric boundary layer, J. Geophys. Res., 106, 20225-20238, doi:10.1029/2000JD000025, 2001.

Vignati, E., Facchini, M. C., Rinaldi, M., Scannell, C., Ceburnis, D., Sciare, J., Kanakidou, M., Myriokefalitakis, S., Dentener, F., and O'Dowd, C. D.: Global scale emission and distribution of seaspray aerosol: sea-salt and organic enrichment, Atmos. Environ., 44, 670-677, 2010.
Wang, M. and Penner, J. E.: Aerosol indirect forcing in a global model with particle nucleation, Atmos. Chem. Phys., 9, 239-260, doi:10.5194/acp-9-239-2009, 2009.

Wang, J., Lee, Y.-N., Daum, P. H., Jayne, J., and Alexander, M. L.: Effects of aerosol organics on cloud condensation nucleus (CCN) concentration and first indirect aerosol effect, Atmos. Chem. Phys., 8, 6325-6339, doi:10.5194/acp-8-6325-2008, 2008.

Wang, J., McGraw, R., Daum, P. H., Sedlacek, A. J., Kleinman, L. I., Senum, G., Lee, Y. N., and Springston, S. R.: Comparison of aerosol and cloud condensation nuclei (CCN) relationship parameterizations with data collected during the 2008 VAMOS Ocean-Cloud-Atmosphere Land Study (VOCALS) field campaign, Third Quarter FY2010 ASR Program Metric Report, available at: http://asr.science.energy.gov/ science/performance-metrics/2010, 2010.

Westervelt, D. M., Moore, R. H., Nenes, A., and Adams, P. J.: Effect of primary organic sea spray emissions on cloud condensation nuclei concentrations, Atmos. Chem. Phys. Discuss., 11, 5757-5784, doi:10.5194/acpd-11-5757-2011, 2011.

Yassaa, N., Peeken, I., Zöllner, E., Bluhm, K., Arnold, S., Spracklen, D., and Williams, J.: Evidence for marine production of monoterpenes, Environ. Chem., 5, 391-401, doi:10.1071/EN08047, 2008.

Yoon, Y. J., Ceburnis, D., Cavalli, F., Jourdan, O., Putaud, J. P., Facchini, M. C., Decesari, S., Fuzzi, S., Sellegri, K., Jennings, S. G., and O'Dowd, C. D.: Seasonal characteristics of the physicochemical properties of North Atlantic marine atmospheric aerosols, J. Geophys. Res.-Atmos., 112, D04206, doi:10.1029/2005JD007044, 2007.

Zender, C. S., Bian, H., and Newman, D.: The mineral Dust Entrainment And Deposition (DEAD) model: Description and 1990's dust climatology, J. Geophys. Res., 108, 4416, doi:10.1029/2002JD002775, 2003.

Zhang, L. M., Gong, S. L., Padro, J., and Barrie, L.: A sizesegregated particle dry deposition scheme for an atmospheric aerosol module, Atmos. Environ., 35, 549-560, 2001. 